\title{
Complexes of Pd(II) and Pt(II) with 9-Aminoacridine: Reactions with DNA and Study of Their Antiproliferative Activity
}

\author{
X. Riera, ${ }^{1}$ V. Moreno, ${ }^{1}$ C. J. Ciudad, ${ }^{2}$ V. Noe, ${ }^{2}$ M. Font-Bardía, ${ }^{3}$ and X. Solans ${ }^{3}$ \\ ${ }^{1}$ Departamento de Química Inorgànica, Facultat de Química, Universitat de Barcelona, Martí i Franquès 1-11, \\ 08028 Barcelona, Spain \\ ${ }^{2}$ Departamento de Bioquimica i Biologia Molecular, Facultat de Biología, Universitat de Barcelona, avenue Diagonal 645, \\ 08028 Barcelona, Spain \\ ${ }^{3}$ Departamento de Cristal.lografia, Mineralogia i Dipòsits Minerals, Facultat de Geología, Universitat de Barcelona, \\ C/ Martí i Franquès s/ $n$, 08028 Barcelona, Spain
}

Received 16 March 2007; Accepted 10 May 2007

Recommended by Giovanni Natile

\begin{abstract}
Four new metal complexes $\{\mathrm{M}=\mathrm{Pd}(\mathrm{II})$ or $\mathrm{Pt}(\mathrm{II})\}$ containing the ligand 9-aminoacridine (9AA) were prepared. The compounds were characterized by FT-IR and ${ }^{1} \mathrm{H},{ }^{13} \mathrm{C}$, and ${ }^{195} \mathrm{Pt}$ NMR spectroscopies. Crystal structure of the palladium complex of formulae $[\mathrm{Pd}(9 \mathrm{AA})(\mu-\mathrm{Cl})]_{2} \cdot 2 \mathrm{DMF}$ was determined by X-ray diffraction. Two 9 -acridine molecules in the imine form bind symmetrically to the metal ions in a bidentate fashion through the imine nitrogen atom and the $\mathrm{C}(1)$ atom of the aminoacridine closing a new five-membered ring. By reaction with phosphine or pyridine, the $\mathrm{Cl}$ bridges broke and compounds with general formulae $[\mathrm{Pd}(9 \mathrm{AA}) \mathrm{Cl}(\mathrm{L})]$ (where $\mathrm{L}=\mathrm{PPh}_{3}$ or py) were formed. A mononuclear complex of platinum of formulae $[\mathrm{Pt}(9 \mathrm{AA}) \mathrm{Cl}(\mathrm{DMSO})]$ was also obtained by direct reaction of 9 -aminoacridine and the complex $\left[\mathrm{PtCl}_{2}(\mathrm{DMSO})_{2}\right]$. The capacity of the compounds to modify the secondary and tertiary structures of DNA was evaluated by means of circular dichroism and electrophoretic mobility. Both palladium and platinum compounds proved active in the modification of both the secondary and tertiary DNA structures. AFM images showed noticeable modifications of the morphology of the plasmid pBR322 DNA by the compounds probably due to the intercalation of the complexes between base pairs of the DNA molecule. Finally, the palladium complex was tested for antiproliferative activity against three different human tumor cell lines. The results suggest that the palladium complex of formula $[\mathrm{Pd}(9 \mathrm{AA})(\mu-\mathrm{Cl})]_{2}$ has significant antiproliferative activity, although it is less active than cisplatin.
\end{abstract}

Copyright (c) 2007 X. Riera et al. This is an open access article distributed under the Creative Commons Attribution License, which permits unrestricted use, distribution, and reproduction in any medium, provided the original work is properly cited.

\section{INTRODUCTION}

Intercalation between parallel base pairs is frequently one of the possible modes of interaction of DNA molecule with active drugs. Classic intercalators are plane aromatic molecules such as acridines, phenantrolines, or phorphyrins. The family of the aminoacridines has been extensively studied [1].

The applications in medicine of these chemical compounds started in early 20th century, when derivatives of crisaniline were found to be active against malaria, and $e u$ flavine and proflavine were used as antibacterial agents. These compounds were replaced by aminacrine (9-aminoacridine) which has similar effects. Afterwards, when the affinity of the acridines for the nucleic acids and their intercalator effects were established $[2,3]$, the research focused on their possible applications as anticancer agents. However, tests conducted with simple acridines had very low activity as antitumor drugs [4]. Systematic studies of the relationship between the antitumor activity and several factors such as the lipophilicity-hydrophilicity of the derivatives, their electronic and steric effects have also been carried out [5]. Recently, 9-aminoacridine has been assayed, in comparison with other acridine derivatives such as pharmacotherapeutic for prion disease Creutzfeldt-Jacob disease (CJD) [6]. The incorporation of bulky groups into the acridine moiety does not allow the intercalation of the chromophor between the DNA base pairs and causes decreasing of the antitumor activity [7].

In parallel, research focussed on the design of compounds containing several acridine molecules joined by carbon chains in order to create a DNA polyintercalator effect $[8-10]$ and on the preparation of coordination compounds with one acridine group as a ligand $[11,12]$ with the objective of obtaining molecules capable of interaction 


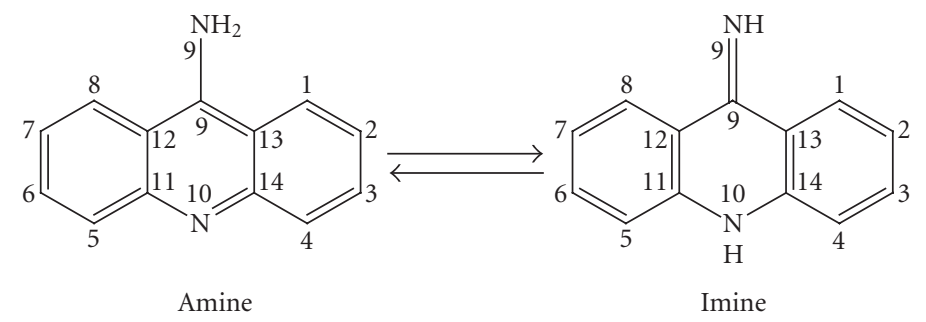

Scheme 1: Schematic representation of the two tautomeric forms of the 9-aminoacridine.

with DNA by intercalation and by metal-base covalent bond. Intercalation is a kinetically labile interaction and the additional fixation of the molecule to DNA by a covalent bond via the metal atom can potentially increase the activity of these systems as antitumor agents.

The 9-aminoacridine (9AA) molecule has two symmetrically distributed nitrogen atoms with nucleophilic properties: the exocyclic $\mathrm{N}(9)$ and the endocyclic $\mathrm{N}(10)$, which can coordinate to transition metal atoms. Two tautomeric forms of the free 9-aminoacridine moiety can be adopted in solution (see Scheme 1).

Rak et al. [13-15] have described the presence of these two forms in solution and have demonstrated that the equilibrium composition changes when the solvent and temperature change, although the authors do not conclude about what isomer is preferentially formed.

An additional interest of this ligand resides in the fact that the DNA interaction occurs by intercalation of 9aminoacridine between the base pairs of the biomolecule and this is, theoritically, compatible with the preferential coordination of platinum to DNA [16-20] by the nitrogen $\mathrm{N}(7)$ of the purine bases on the major groove.

Sundquist et al. [21] have described the synthesis of coordination compounds of formulae cis-[PtCl(9AA)$\left.\left(\mathrm{NH}_{3}\right)_{2}\right]\left(\mathrm{NO}_{3}\right)$ and cis- $\left.\mathrm{Pt}(9 \mathrm{AA})_{2}\left(\mathrm{NH}_{3}\right)_{2}\right]\left(\mathrm{NO}_{3}\right)_{2}$ prepared reacting a derivative of cisplatin with the ligand 9aminoacridine (9AA). In the two complexes, the ligand is coordinated in its imine form, which binds to the platinum atom in a monodentate fashion by the exocyclic nitrogen atom. Natile and col. [22-24] have investigated the reaction of 9-[(2-aminoethyl)amino] acridines with platinum(II) substrates and also have studied the endocyclic versus exocyclic N-coordination to platinum(II) and the role of metal ions and hydrogen bond acceptors in the tautomeric equilibrium of nitro-derivatives of 9-aminoacridines.

More recently, the interaction of 9-aminoacridinecarboxamide platinum complexes with DNA has been investigated, particulary their DNA sequence specificity and binding kinetics [25]. The presence of the 9-amino substituent produces the effect of shifting away from runs of consecutive guanines (the main binding site for cisplatin). However, an acridinecarboxamide platinum complex showed a similar sequence specifity to cisplatin. The same authors prepared cis-dichloroplatinum(II) complexes tethered to 9aminoacridine-4-carboxamides and assessed their activity in several resistant cell lines in vitro [26]. The sequence specifity and kinetics of DNA adduct formation for the aforementioned compounds with HeLa cells were also compared with those of cisplatin, resulting 4-fold faster for DNA-targeted Pt complexes [27]. Platinum-acridine conjugates were also prepared and tested against several tumor cell lines resulting active at micromolar concentrations. Mono- and bisacridinylthiourea platinum (II) complexes were synthesized by Bierbach's research group [28-30] with the aim of studying DNA strands cleavage and binding modes. The interaction of ACRAMTU-Pt complexes \{ACRAMTU $=1-[2-$ (acridin-9-ylamino)ethyl]-1,3-dimethylthiourea $\}$ with DNA have been extensively studied by Bierbach et al. [31-36]. Recent results from their biophysical and biochemical studies suggest interesting binding mechanisms to the DNA molecule.

Finally, metal derivatives of 9-aminoacridine have been synthesized as precursors for radio iodination for potential use in radionuclide therapy [37].

Here, the synthesis of new $\mathrm{Pd}(\mathrm{II})$ and $\mathrm{Pt}(\mathrm{II})$ complexes of the classic intercalator 9-aminoacridine (9AA), where the ligand acts as a $(\mathrm{C}, \mathrm{N})^{-}$bidentate group, is presented. The study of their chemical, structural properties and reactivity with DNA, as well as their antiproliferative behavior with selected tumor cell lines are also described.

\section{EXPERIMENTAL}

\subsection{Materials and methods}

The complexes were prepared using $\mathrm{K}_{2}\left[\mathrm{PdCl}_{4}\right]$ and $\mathrm{K}_{2}\left[\mathrm{PtCl}_{4}\right]$ from Johnson Matthey (Reading, UK); the solvents used were purchased from Fluka (Madrid, Spain); and 9-aminoacridine, Calf Thymus-DNA, and EDTA from Sigma-Aldrich (Madrid, Spain).

Elemental analyses were carried out on a Carlo Erba 1500 microanalyzer at the Serveis Científico-Tècnics of the University of Barcelona. Chlorine in the compounds was analyzed by the Shöniger method and potentiometric titration in a titroprocessor Metrohm 636 provided with a silver combined electrode. Platinum was determined by flameless atomic absorption spectroscopy (FAAS) using a Unicam 939 AA spectrometer with graphite furnace; the measurements were done by addition and the sample was dissolved in DMF to a concentration of $0.3 \mathrm{mM}$. Palladium was measured by inductively coupled plasma-optical emission spectroscopy (ICP-OES) using a Thermo Jarrell Ash polyscan GIE in standard conditions at a wavelength of $340-458 \mathrm{~nm}$. The 
samples required prior mineralization to ICP after which they were digested with concentrated nitric and perchloric acids in pyrex tubes at $220^{\circ} \mathrm{C}$; palladium was dissolved in $100 \mathrm{ml}$ of Milli-Q water in acid medium [38]. The IR spectra were recorded in a solid state (KBr pellets) on an FT-IR Nicolet $5 \mathrm{DZ}$ spectrometer in the $4000-400 \mathrm{~cm}^{-1}$ range and on an FT-IR Bomen DA-3 (CsBr pellets) for the $400-200 \mathrm{~cm}^{-1}$ range. ${ }^{1} \mathrm{H}\left\{{ }^{13} \mathrm{C}\right\},{ }^{13} \mathrm{C}\left\{{ }^{1} \mathrm{H}\right\}$, and ${ }^{195} \mathrm{Pt}\left\{{ }^{1} \mathrm{H}\right\}$ NMR spectra were recorded on a Bruker DRX 250 spectrometer using $\mathrm{CDCl}_{3}$ as solvent in the case of ${ }^{1} \mathrm{H}$ and ${ }^{13} \mathrm{C}$ spectra and DMSO- $d_{6}$ in the case of ${ }^{195} \mathrm{Pt}$ spectrum due to the low solubility in $\mathrm{CDCl}_{3}$ of the platinum complex. Chemical shifts were measured relative to TMS in the case of ${ }^{1} \mathrm{H}$ and ${ }^{13} \mathrm{C}$, and to $\mathrm{K}_{2} \mathrm{PtCl}_{6}$ in the case of ${ }^{195} \mathrm{Pt}$ NMR spectra. Mass spectra were run on a Fisons VG Quattro triple quadrupole analyzer in the $1800-200 \mathrm{~m} / \mathrm{z}$ range using $\mathrm{MeCN}$ as solvent under electrospray (ESP-MS).

\subsection{Syntheses of the complexes}

$[P d(9 A A)(\mu-C l)]_{2} \cdot 2 D M F$

A solution of $0.192 \mathrm{~g}(0.50 \mathrm{mM})$ of cis- $\left[\mathrm{PdCl}_{2}(\mathrm{PhCN})_{2}\right]$ [39] in $10 \mathrm{~mL}$ of $\mathrm{CHCl}_{3}$ was added to $40 \mathrm{~mL}$ of a solution of $0.097 \mathrm{~g}(0.50 \mathrm{mM})$ of 9 -aminoacridine in $\mathrm{CHCl}_{3}$. The mixture was refluxed at $60^{\circ} \mathrm{C}$ for 12 hours. A brown solid was formed after cooling. The resulting precipitate was washed with ethanol and ethylic ether, and dried overnight under silica gel. The solid was dissolved in a minimum amount (ca. $5 \mathrm{~mL}$ ) of a mixture of $\mathrm{CHCl}_{3}: \mathrm{DMF}$ (100:50) and the solution was eluted in $\mathrm{SiO}_{2}$ column $(30 \times 2 \mathrm{~cm})$ using $\mathrm{CHCl}_{3}: \mathrm{DMF}$ (100:50) as eluent. The orange band collected from the $\mathrm{SiO}_{2}$ column was concentrated by evaporation under vacuum and a brownish solid was obtained. Adequate crystals for X-ray diffraction were obtained from a fraction collected from the column after slow evaporation of the solvent Yield: $35 \%$. $\left[\mathrm{Pd}_{2} \mathrm{C}_{32} \mathrm{H}_{32} \mathrm{~N}_{6} \mathrm{Cl}_{2} \mathrm{O}_{2}\right]$ requires: $\mathrm{C}$, 47.07; N, 10.29; $\mathrm{H}, 3.92$; found: $\mathrm{C}, 46.75 ; \mathrm{N}, 10.40 ; \mathrm{H}, 4.20$.

\section{$\left[P d(9 A A) C l\left(p y-d_{5}\right)\right]$}

This compound was obtained at NMR scale. $0.008 \mathrm{~g}$ $(0.0098 \mathrm{mM})$ of $[\mathrm{Pd}(9 \mathrm{AA})(\mu-\mathrm{Cl})]_{2} \cdot 2 \mathrm{DMF}$ were dissolved in $0.7 \mathrm{~mL}$ of DMSO- $d_{6}$ and 2 drops of pyridine- $d_{5}$. The solution immediately changed its color from brownish to strong yellow.

\section{[PdCl(9AA) $\left.\left(\mathrm{PPh}_{3}\right)\right]$}

In a first step, this compound was prepared at NMR scale, but further it was also isolated in a solid state. $0.004 \mathrm{~g}$ $(0.0049 \mathrm{mM})$ of $[\mathrm{Pd}(\mu-\mathrm{Cl})(9 \mathrm{AA})]_{2} \cdot 2 \mathrm{DMF}$ were dissolved in $0.4 \mathrm{~mL}$ of DMSO- $d_{6}$ and $0.0026 \mathrm{~g}(0.0098 \mathrm{mM})$ of triphenylphosphine dissolved in $0.3 \mathrm{~mL}$ of DMSO- $d_{6}$ were added. The solution changed immediately from brown color to strong yellow.

The product in solid state was prepared by the following procedure: $0.0257 \mathrm{~g}(0.0098 \mathrm{mM})$ of triphenyl/phosphine, dissolved in the minimum amount of acetone were added to a suspension of $0.04 \mathrm{~g}(0.049 \mathrm{mM})$ of $[\mathrm{Pd}(\mu-\mathrm{Cl})(9 \mathrm{AA})]_{2}$
- 2DMF in $30 \mathrm{~mL}$ of acetone. The mixture was stirred at room temperature for 1 hour until the solid disappeared. The final yellow solution was concentrated in a rotavapor and an oil was obtained. $20 \mathrm{~mL}$ of diethylether were added to the oil and a yellow precipitate was formed which was filtered and dried. Yield: $82 \%$. [ $\mathrm{PdC}_{31} \mathrm{H}_{24} \mathrm{~N}_{2} \mathrm{C} 1 \mathrm{P}$ ] requires: $\mathrm{C}, 62.32 ; \mathrm{N}$, 4.69; H, 4.02; found: C, 62.80; N, 4.50; H, 4.20.

\section{[PtCl(9AA)(DMSO)]}

A suspension of $0.106 \mathrm{~g}(0.25 \mathrm{mM})$ of cis- $\left[\mathrm{PtCl}_{2}(\mathrm{DMSO})_{2}\right]$ and $20 \mathrm{~mL}$ of methanol was refluxed until the solid dissapeared. A solution of $0.097 \mathrm{~g}(0.50 \mathrm{mM})$ of 9 -aminoacridine in the minimum amount of methanol was added and the resultant mixture was refluxed for 16 hour. When the solvent was eliminated, a brownish solid remained in the bottle. The solid was dissolved in $20 \mathrm{~mL}$ of acetone. The solution was filtered on Ceolite, and finally, n-hexane was added until precipitation of a yellow solid, which was filtered, washed with small amounts of n-hexane, and dried at the air. Yield: $51 \%$. $\mathrm{PtC}_{15} \mathrm{H}_{15} \mathrm{~N}_{2}$ ClOS requires: C, 35.86; N, 5.58; H, 2.99; S, 6.37; found: C, 36.10; N, 5,40; H, 3.10; S, 6.40.

\subsection{X-ray diffraction}

$\mathrm{A}[\mathrm{Pd}(9 \mathrm{AA})(\mu-\mathrm{Cl})]_{2} \cdot 2 \mathrm{DMF}$ prismatic crystal $(0.1 \times 0.1 \times$ $0.2 \mathrm{~mm}$ ) was selected and mounted on an Enraf-Nonius CAD4 four-circle diffractometer. Unit-cell parameters were determined from automatic centering of 25 reflections $(12<$ $\Theta<21^{\circ}$ ) and refined by least-squares method. Intensities were collected with graphite monochromatized MoK $\alpha$ radiation, using $w / 2 \Theta$ scan technique. 4911 reflections were measured in the range $2.60>\Theta>29.97 .4715$ of which were non-equivalent by symmetry $\left(\mathrm{R}_{\text {int }}(\right.$ on $\left.\mathrm{I})=0.018\right) .3681$ reflections were assumed as observed applying the condition I $>2 \sigma(\mathrm{I})$. Three reflections were measured every two hours as orientation and intensity control; significant intensity decay was not observed. Lorentz-polarization, but not absorption corrections, was made.

The structure was solved by direct methods using SHELXS computer program [40] for determination of crystal structures and refined by full-matrix least-squares method with SHELX93 computer program [41] using 4665 reflections, (very negative intensities were not assumed). The function minimized was $\Sigma \mathrm{w}\left[(\mathrm{Fo})^{2}-(\mathrm{Fc})^{2}\right]^{2}$, where $\mathrm{w}=$ $\left[\sigma^{2}(\mathrm{I})+(0.0683 \mathrm{P})^{2}\right]^{-1}$, and $\mathrm{P}=\left[(\mathrm{Fo})^{2}+2(\mathrm{Fc})^{2}\right] / 3 ; \mathrm{f}, \mathrm{f}^{\prime}$, and $\mathrm{f}^{\prime \prime}$ were taken from the international tables of X-Ray crystallography [42]. All $\mathrm{H}$ atoms were computed and refined with an overall isotropic temperature factor, using a riding model. Hydrogen coordinates as well as anisotropic thermal parameters are included as supplementary material.

\subsection{Formation of drug-DNA complexes}

Stock solutions of each compound ( $1 \mathrm{mg} / \mathrm{mL}$ ) were stored in the dark at room temperature until used. Drug-DNA complex formation was accomplished by addition of CT DNA (Calf thymus DNA) to aliquots of each of the compounds at different concentrations in TE buffer $(50 \mathrm{mM} \mathrm{NaCl}, 10 \mathrm{mM}$ 
Tris- $\mathrm{HCl}, 0.1 \mathrm{mM}$ EDTA, $\mathrm{pH}=7.4)$. The amount of compound added to the DNA solution was designated as $\left(r_{i}\right)$ (the input molar ratio of $\mathrm{Pt}, \mathrm{Pd}$, or 9 -aminoacridine to nucleotide). The mixture was incubated at $37^{\circ} \mathrm{C}$ for 24 hours.

\subsection{Circular Dichroism}

The CD spectra of the complex-DNA compounds (DNA concentration $20 \mathrm{mg} / \mathrm{mL},\left(\mathrm{r}_{\mathrm{i}}\right)=0.05,0.10,0.30$, and 0.50 ) were recorded at room temperature on a JASCO J720 spectropolarimeter with a $450 \mathrm{~W}$ xenon lamp using a computer for spectral subtraction and noise reduction. Each sample was scanned twice in a range of wavelengths between 220 $360 \mathrm{~nm}$. The CD spectra drawn are the mean of three independent scans. The data are expressed as mean residue molecular ellipticity $[\Theta]$ in degree $\mathrm{cm}^{-1} \cdot \mathrm{dmol}^{-1}$.

\subsection{Determination of Pt and Pd bound to DNA}

The drug-DNA complex solutions used for CD experiments were kept; the DNA was afterwards precipitated twice with 2.5 volumes of cold ethanol and 0.1 volume of $3 \mathrm{M} \mathrm{NaAcO}$, $\mathrm{pH}$ 4.8. The DNA was washed in 70\% ethanol and suspended in $1 \mathrm{~mL}$ of TE buffer. The amount of DNA in each sample was measured by a double-beam Shimazdu UV-2101-PC spectrometer. The platinum and palladium bound to the DNA was determined by Inductively Coupled Plasma-Mass spectrometer (ICP-MASS) Perkin Elmer ELAN-500. The assays were performed in triplicate.

\subsection{Electrophoretic mobility in agarose gel}

Commercial solution of pBR322 plasmid DNA, $0.25 \mu \mathrm{g} / \mu \mathrm{L}$ was used for electrophoretic mobility experiments.

$4 \mu \mathrm{L}$ of charge marker were added to aliquot parts of $20 \mu \mathrm{L}$ of the adducts complex: DNA previously incubated at $37^{\circ} \mathrm{C}$ for 24 hours. The mixture was electrophoretized in agarose gel ( $1 \%$ in TBE buffer) for 5 hours at $1.5 \mathrm{~V} / \mathrm{cm}$. Afterwards, the DNA was dyed with thydium bromide solution $(0.5 \mu \mathrm{g} / \mathrm{mL}$ en TBE) for 20 minutes.

Samples of DNA and adduct cisplatin: DNA were used as control. The experiment was carried out in an ECOGEN horizontal tank connected to a PHARMACIA GPS 200/400 variable potential power supply.

\subsection{Atomic force microscopy (TMAFM)}

pBR322 DNA was heated at $60^{\circ}$ for 10 minutes to obtain OC form. Stock solution is $1 \mathrm{mg} / \mathrm{mL}$ in a buffer solution of HEPES. Each sample contains $1 \mu \mathrm{L}$ of DNA pBR322 of concentration $0.25 \mu \mathrm{g} / \mu \mathrm{L}$ for a final volume of $50 \mu \mathrm{L}$. The amount of drug added was expressed as $\left(r_{i}\right)$, ratio between the molar concentration of drug to number of base pairs.

Images are obtained with a Nanoscope III multimode AFM of Digital Instruments Inc. operating in tapping mode.

\subsection{Tumor cell lines and culture conditions}

Three different tumor cell lines were used in these experiments: MCF-7 breast cancer cell line, DU-145 prostate cancer cell line, and HeLa cervix cancer cell line. The protocols used in each case were the following: MCF-7 cells were routinely maintained in DMEM medium supplemented with $10 \%$ of fetal bovine serum (FBS), DU-145 cells in RPMI medium supplemented with $10 \%$ of FBS and $2 \mathrm{mmol} / \mathrm{L}$ of glutamine, and HeLa cells in Ham's F-12 medium. The cultures were kept in an incubator at a highly humidified atmosphere of $95 \%$ air with $5 \% \mathrm{CO}_{2}$ at $37^{\circ} \mathrm{C}$.

The cells were collected from the medium and were counted with a hemocytometer. Aliquot parts of $100 \mu \mathrm{L}$ were placed in 96 wells (2000 or 3000 cells per well for MCF-7 i DU-145, resp.). The cells were preincubated without drug for 48 hours (MCF-7) and for 72 hours (DU-145), at $37^{\circ} \mathrm{C}$ and $5 \% \mathrm{CO}_{2}$ atmosphere with $95 \%$ of relative humidity. Immediately before to be used, the complexes were solved in sterile water or DMSO/ $\mathrm{H}_{2} \mathrm{O}$ mixture at a stock concentration of $1 \mathrm{mg} / \mathrm{mL}$ and filtered. Aliquot parts of these solutions were added to each well (between 20 and $50 \mu \mathrm{L}$ of compound depending on the final concentration required). In any case, the concentration of DMSO in the solution in contact with the cells was higher than $1 \%$. After addition of the compound, the cells were incubated for 48 hours in the above conditions. $20 \mu \mathrm{L}$ of MTT solution ( $5 \mathrm{mg} / \mathrm{mL}$ in PBS) were added to each well and were incubated for 3-4 hours more. Then, $150 \mu \mathrm{L}$ of solution of solubilization of MTT-formazan crystalls formed (500 mL DMF, $200 \mathrm{~g}$ SDS, $20 \mathrm{~mL}$ glacial acetic acid, $10 \mathrm{~mL}$ of $\mathrm{HCl} 2 \mathrm{M}$ and water until $1 \mathrm{~L}$ ) were added. The cellular density was calculated in both, the control cultures and the treated cultures, measuring the absorbance at $570 \mathrm{~nm}$ in an ELISA reader Labsystems Multiskan Multisoft. The $\mathrm{IC}_{50}$ values were calculated from the graphic representation of cell survival percentage in function of drug (in $\mu \mathrm{M}$ ). The data were obtained from four independent experiments.

In the case of the HeLa cells, the methodology followed was basically identical with the following differences: number of cells per well, 2000, preincubation for 24 hours, incubation for 24 hours, and concentrations of $0.1,1,10$ i $50 \mu \mathrm{M}$; solution of solubilization of MTT-formazan crystalls, DMSO; wavelength of reading, $490 \mathrm{~nm}$; reader of microplates ELISA, ELX800G from Bio-Tek Instruments Inc.

\section{RESULTS AND DISCUSSION}

The main objective of this work was the synthesis, characterization, and biological studies of compounds of general formulae cis- $\left[\mathrm{MCl}_{2}(9 \mathrm{AA})_{2}\right](\mathrm{M}=\mathrm{Pd} \circ \mathrm{Pt}, 9 \mathrm{AA}=9$ aminoacridine).

One of the most common synthetic routes of complexes cis- $\left[\mathrm{MX}_{2}(\mathrm{~L})\right]$ or $c i s-\left[\mathrm{MX}_{2}(\mathrm{~L})_{2}\right]$ consists on the reaction of the ligand (L) with the compounds $\mathrm{M}_{2}^{\mathrm{I}}\left[\mathrm{MCl}_{4}\right]$ (where $\mathrm{M}^{\mathrm{I}}=$ $\mathrm{Na}$ or $\mathrm{K}$, and $\mathrm{M}=\mathrm{Pd}$ or $\mathrm{Pt}$ ). The reaction between the 9aminoacridine and the compounds $\mathrm{K}_{2}\left[\mathrm{MCl}_{4}\right](\mathrm{M}=\mathrm{Pd} \circ \mathrm{Pt})$ was not successful due to their low solubility in organic solvents. (i.e., methanol, ethanol, $\mathrm{CHCl}_{3}$, acetone), in which the ligand is soluble. The use of $\mathrm{Na}_{2}\left[\mathrm{PdCl}_{4}\right]$ yielded a brown 


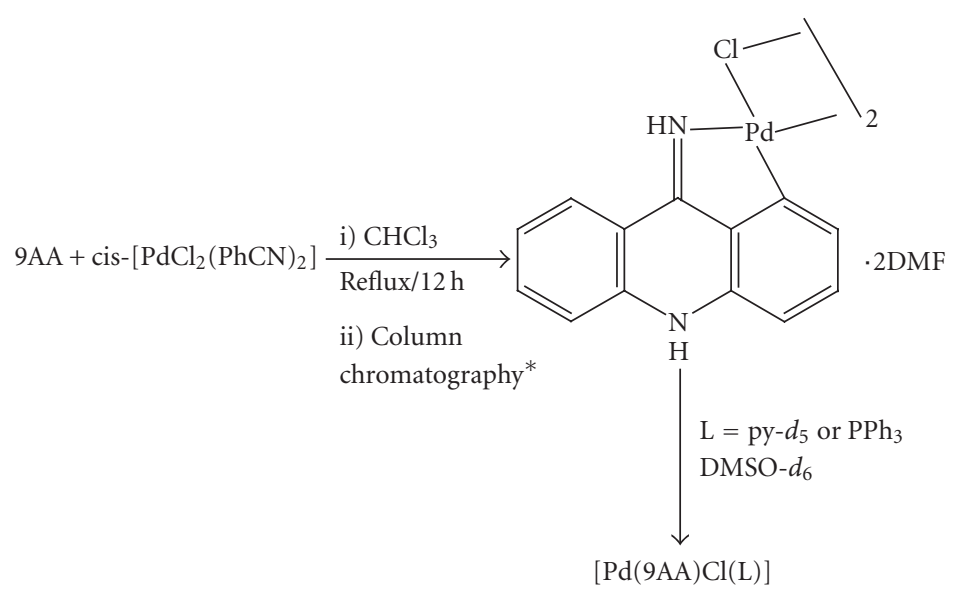

(a)

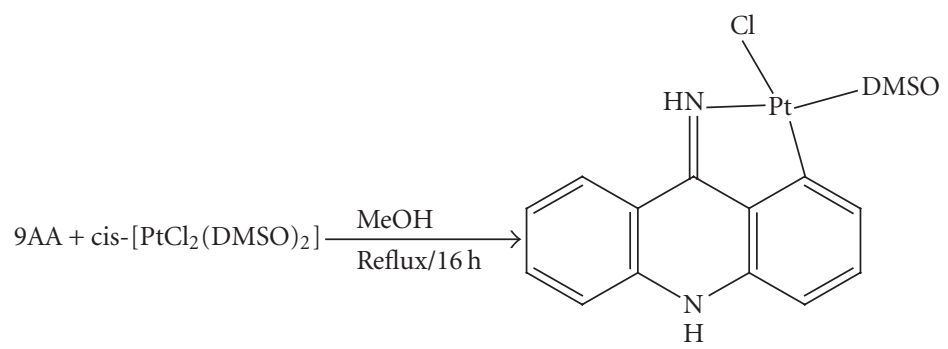

(b)

Scheme 2: Scheme of the synthesis of the complexes (a) $[\mathrm{Pd}(9 \mathrm{AA})(\mu-\mathrm{Cl})]_{2}$ and $[\mathrm{Pt}(9 \mathrm{AA})(\mathrm{L})]\left(\mathrm{L}=\right.$ py- $d_{5}$ or $\left.\mathrm{PPh} \mathrm{h}_{3}\right)$ and $(\mathrm{b})$ $[\mathrm{Pt}(9 \mathrm{AA}) \mathrm{Cl}(\mathrm{DMSO})]:{ }^{*} \mathrm{De} \mathrm{SiO}_{2}$. The eluted used was a mixture $\mathrm{CHCl}_{3}: \mathrm{DMF}(100: 50)$.

solid insoluble in the usual solvents which could not be completly characterized. The ${ }^{1} \mathrm{H}$ NMR and elemental analysis results suggest that the solid is mainly a mixture of the coordination compounds with 1:1 and 1:2 (metal:ligand) stochiometries together with lower concentration unidentified species.

Using the compound cis- $\left[\mathrm{PdCl}_{2}(\mathrm{PhCN})_{2}\right]$ as starting material in stronger reaction conditions and after purification of the reaction product by column chromatography, the dimeric cyclopalladate complex bridged through chlorine atoms of formula $[\mathrm{Pd}(9 \mathrm{AA})(\mu-\mathrm{Cl})]_{2}$ (see Scheme $\left.2(\mathrm{a})\right)$ was isolated.

The cycloplatinated compound of formulae [Pt(9AA)Cl(DMSO)] (Scheme 2(b)), was synthesized by reaction of 9aminoacridine and cis- $\left[\mathrm{PtCl}_{2}(\mathrm{DMSO})_{2}\right], 2: 1$, in methanol reflux. It was not possible to isolate the coordination compound cis- $\left[\mathrm{PtCl}_{2}(\mathrm{~L})_{2}\right]$ in spite of that several reaction times (between 30 minutes and 24 hours) and temperatures (between 25 and $70^{\circ} \mathrm{C}$ ) were assayed. The activation of the $\mathrm{C}-\mathrm{H}$ bond is clearly favored in the conditions used. To the authors' knowledge, $[\mathrm{Pd}(9 \mathrm{AA})(\mu-\mathrm{Cl})]_{2}$ and $[\mathrm{Pt}(9 \mathrm{AA}) \mathrm{Cl}(\mathrm{DMSO})]$ are the first metallocycle derivatives of the 9-aminoacridine, where the ligand behaves as a bidentate $(\mathrm{C}, \mathrm{N})^{-}$group. Two cycloplatinated compounds derivatives of 1-nitro-9$[\{(2$-alkylamino $)$ ethyl $\}$ amino $]$ acridine $\left\{\right.$ alkyl $=\mathrm{CH}_{2}-\mathrm{CH}_{3}$ or $\left.\mathrm{CH}_{3}\right\}$ were previously described by Ceci et al. [22]. In those compounds, the ligand acts as a monoanionic terdentate $\left(\mathrm{C}, \mathrm{N}, \mathrm{N}^{\prime}\right)^{-}$, where the platinum atom binds simultaneously to two exocyclic nitrogen atoms and to the $\mathrm{C}^{8}$ carbon, with the fourth coordination site occupied by a chlorine atom.

\subsection{Reactivity of the "Pd( $\mu-C I)_{2} P d$ " moiety in the dinuclear compound $[\mathrm{Pd}(9 A A)(\mu-\mathrm{Cl})]_{2}$}

The reaction of the compound $[\mathrm{Pd}(9 \mathrm{AA})(\mu-\mathrm{Cl})]_{2}$ with pyridine- $d_{5}\left(\right.$ py- $\left.d_{5}\right)$ or with triphenylphosphine $\left(\mathrm{PPh}_{3}\right)$ yielded the corresponding monomeric compounds $[\mathrm{Pd}(9 \mathrm{AA}) \mathrm{Cl}(\mathrm{L})]\left(\mathrm{L}=\mathrm{py}-d_{5}, \mathrm{PPh}_{3}\right) \quad($ see Scheme $2(\mathrm{a}))$. The lability of the $\mathrm{Pd}-\mathrm{N}$ bond is lower than that described for cyclopalladated compounds of five-membered rings derivatives of $N$-benzylidenaniline [43] which react with triphenylphosphine to give $\left[\mathrm{Pd}\left(\mathrm{C}^{\wedge} \mathrm{N}\right) \mathrm{X}(\mathrm{L})_{2}\right]$ after break of the $\mathrm{Pd}-\mathrm{N}$ bond (Scheme 2(a)). In spite of the addition of excess of pyridine- $d_{5}$ or $\mathrm{PPh}_{3}$, the substitution of the second chloride ligand was not observed.

The new compounds prepared $[\mathrm{Pd}(9 \mathrm{AA})(\mu-\mathrm{Cl})]_{2}$. $2 \mathrm{DMF},[\mathrm{Pd}(9 \mathrm{AA}) \mathrm{Cl}(\mathrm{L})] \quad\left(\mathrm{L}=\mathrm{py}-d_{5}\right.$ or $\left.\mathrm{PPh}_{3}\right)$ and $[\mathrm{Pt}(9 \mathrm{AA}) \mathrm{Cl}(\mathrm{DMSO})]$ were characterized by IR and ${ }^{1} \mathrm{H}$, ${ }^{13} \mathrm{C},{ }^{31} \mathrm{P}\left\{\right.$ in the case of $\left.\left[\mathrm{Pd}(9 \mathrm{AA}) \mathrm{Cl}\left(\mathrm{PPh}_{3}\right)\right]\right\}$ and ${ }^{195} \mathrm{Pt}\{$ for [Pt(9AA)Cl(DMSO)] $\}$ NMR spectroscopies. Molecular and 
crystal structures for the cyclopalladated $[\mathrm{Pd}(9 \mathrm{AA})(\mu-\mathrm{Cl})]_{2}$. 2DMF were obtained by X-ray diffraction.

\section{2. $F T-I R$}

The FT-IR spectra in the range $4000-400 \mathrm{~cm}^{-1}$ for the 9-aminoacridine and the complexes $[\mathrm{Pd}(9 \mathrm{AA})(\mu-\mathrm{Cl})]_{2}$. 2DMF, $\left[\mathrm{Pd}(9 \mathrm{AA}) \mathrm{Cl}\left(\mathrm{PPh}_{3}\right)\right]$, and $[\mathrm{Pt}(9 \mathrm{AA}) \mathrm{Cl}(\mathrm{DMSO})]$ were recorded.

In the zone between $1670-1550 \mathrm{~cm}^{-1}$ the stretching $\nu(>\mathrm{C}=\mathrm{N}-)^{1}$ and bending $\delta\left(\mathrm{NH}_{2}\right)$ bands can be assigned. The $\delta\left(\mathrm{NH}_{2}\right)$ band of the free ligand appears at $1670 \mathrm{~cm}^{-1}$. In the spectrum of the compound $\left[\mathrm{Pd}(9 \mathrm{AA}) \mathrm{Cl}\left(\mathrm{PPh}_{3}\right)\right]$, the form of the bands between $550-520 \mathrm{~cm}^{-1}$, corresponding to the triphenylphosphine molecules [44], confirms the coordination of the palladium atom to only one molecule of $\mathrm{PPh}_{3}$.

In the case of the complex [Pt(9AA)Cl(DMSO)], the IR spectrum shows an additional band at $1032 \mathrm{~cm}^{-1}$ assigned to the stretching vibration $v(>\mathrm{S}=\mathrm{O})$ of the dimethylsulfoxide molecule coordinated to platinum atom through the sulphur atom [45].

\section{3. ${ }^{1} H$ NMR spectra}

The ${ }^{1} \mathrm{H}$ NMR spectra assignments, corresponding to the free ligand and the complexes $[\mathrm{Pd}(9 \mathrm{AA})(\mu-\mathrm{Cl})]_{2}$. 2DMF, $[\mathrm{Pd}(9 \mathrm{AA}) \mathrm{Cl}(\mathrm{L})] \quad\left(\mathrm{L}=\right.$ py- $d_{5}$ or $\left.\mathrm{PPh}_{3}\right)$ and $[\mathrm{Pt}(9 \mathrm{AA}) \mathrm{Cl}(\mathrm{DMSO})]$, are collected in Table 1 . All the spectra were recorded in DMSO- $d_{6}$ at room temperature with exception of the complex [Pt(9AA)Cl(DMSO)] which was recorded in acetone- $d_{6}$. COSY and TOCSY experiments were used for the assignment.

The spectrum of the free ligand shows four signals in the aromatic zone, which indicates chemical equivalence of the protons localized to both sides of the symmetry plane of the molecule. The signals were assigned as described in the literature [46]. The spectra of the complexes are similar: they present seven signals (between 6 and $9 \mathrm{ppm}$ ) assigned to the protons of the aromatic $\mathrm{CH}$ groups, which demonstrates the loss of symmetry of the ligand as a consequence of the binding to the metal ion. The presence of only seven resonances indicates the formation of a $\sigma\left(\mathrm{Pd}-\mathrm{Csp}^{2}\right.$, aryl $)$ bond. On the other side, two singlets assigned to the protons of $\mathrm{NH}$ groups appear, confirming the imino form for the ligand.

The value of the chemical shift of proton $\mathrm{NH}^{10}$ is $\delta=$ $11.65 \mathrm{ppm}$ for the palladium complexes and $\delta=10.73 \mathrm{ppm}$ for the platinum complex. This suggests the presence in solution of a hydrogen bond between the proton bound to endocyclic nitrogen and the DMF molecule present in the three palladium compounds. This type of interaction can also be observed in solid state, in the crystal structure of compound $[\operatorname{Pd}(9 \mathrm{AA})(\mu-\mathrm{Cl})]_{2} \cdot 2 \mathrm{DMF}$. In Figure 2 the $2 \mathrm{D}$ spectrum for this complex is represented.

The spectra of the monomeric palladium compounds $[\mathrm{Pd}(9 \mathrm{AA}) \mathrm{Cl}(\mathrm{L})]\left(\mathrm{L}=\right.$ py- $d_{5}$ or $\left.\mathrm{PPh}_{3}\right)$ show, as most significant feature, a strong upshift of the $\mathrm{H}^{2}$ (see Table 1). This fact is usually observed for the proton in orto position relative to metallated carbon atom in cyclopalladate complexes similar to those studied here [47] and it is due to the proximity of this proton to the aromatic ring of pyridine- $d_{5}$ or triphenylphosphine in cis position relative to the metallated carbon atom.

A noticeable feature in the spectrum of $[\mathrm{Pd}(9 \mathrm{AA})$ $\left.\mathrm{Cl}\left(\mathrm{PPh}_{3}\right)\right]$ (see Figure 1) is that the signal of the iminic proton $\left(\mathrm{NH}^{9}\right)$ appears as a doublet due to the coupling with the ${ }^{31} \mathrm{P}\left({ }^{3} J_{\mathrm{P}-\mathrm{H}^{9}}=5 \mathrm{~Hz}\right)$ nucleous. For the same reason, the $\mathrm{H}^{2}$ resonance appears as a doublet of doublets $\left({ }^{4} J_{\mathrm{P}-\mathrm{H}^{2}}=5 \mathrm{~Hz}\right)$. The values of these coupling constants are similar to those of analogue compounds described in the literature [48].

In the spectrum of the platinum derivative (see Figure 3 ), a signal at $3.49 \mathrm{ppm}$ assigned to the protons of the two methyl groups of DMSO appears. The value of the chemical shift as well as the presence of satellites due to the coupling with the ${ }^{195} \mathrm{Pt}$ nucleous $\left({ }^{3} J_{\mathrm{Pt}-\mathrm{H}(\mathrm{dmso})}=21 \mathrm{~Hz}\right)$ indicate that the DMSO molecule is coordinated to the metal ion. The coupling between the platinum atom and the $\mathrm{H}^{2}\left({ }^{3} \mathrm{~J}_{\mathrm{Pt}-\mathrm{H}^{2}}=48 \mathrm{~Hz}\right)$ was also identified. On the contrary, the coupling between the iminic proton $\mathrm{NH}^{9}$, was not observed, probably due to the width of the signal.

\section{4. $N M R^{13} C\left\{{ }^{1} H\right\}$}

${ }^{13} \mathrm{C}\left\{{ }^{1} \mathrm{H}\right\}$ NMR spectra of the free ligand and the complexes $[\mathrm{Pd}(9 \mathrm{AA})(\mu-\mathrm{Cl})]_{2} \cdot 2 \mathrm{DMF},\left[\mathrm{Pd}(9 \mathrm{AA}) \mathrm{Cl}\left(\mathrm{PPh}_{3}\right)\right]$, and $[\mathrm{Pt}(9 \mathrm{AA}) \mathrm{Cl}(\mathrm{DMSO})]$ were obtained.

The signals observed in the ${ }^{13} \mathrm{C}\left\{{ }^{1} \mathrm{H}\right\}$ for the ligand were assigned as previously described in the literature [21]. The spectra of the complexes $[\mathrm{Pd}(9 \mathrm{AA})(\mu-\mathrm{Cl})]_{2} \cdot 2 \mathrm{DMF}$, $\left[\mathrm{Pd}(9 \mathrm{AA}) \mathrm{Cl}\left(\mathrm{PPh}_{3}\right)\right]$ and $[\mathrm{Pt}(9 \mathrm{AA}) \mathrm{Cl}(\mathrm{DMSO})]$ show very similar general characteristics. Bidimensional heterocorrelation experiments ${ }^{1} \mathrm{H}-{ }^{13} \mathrm{C}$ were used for the assignments.

The seven crossover single peaks of the aromatic zone in bidimensional experiments (see Figure 3), which are coincidental with the most intense resonances in the ${ }^{13} \mathrm{C}\left\{{ }^{1} \mathrm{H}\right\}$ NMR spectrum, confirm the formation of a $\sigma\left(\mathrm{M}-\mathrm{Csp}^{2}\right.$, aryl $)$ ( $\mathrm{M}=\mathrm{Pd}$ or $\mathrm{Pt}$ ) bond.

${ }^{13} \mathrm{C}\left\{{ }^{1} \mathrm{H}\right\}$ NMR spectra show as well five signals without crossover peaks in herecorrelation study that were assigned to quaternary carbons. The less strong of these resonances that appears downshift to the free ligand was assigned to the metallated carbon $\left(\mathrm{C}^{1}\right)$. This assignment is confirmed by the existence of ${ }^{195} \mathrm{Pt}$ satellites in the compound $[\mathrm{Pt}(9 \mathrm{AA}) \mathrm{Cl}(\mathrm{DMSO})]$ and for the doublet form due to the coupling with ${ }^{31} \mathrm{P}$ nucleous in the complex $\left[\mathrm{Pd}(9 \mathrm{AA}) \mathrm{Cl}\left(\mathrm{PPh}_{3}\right)\right]$.

The $\mathrm{C}^{9}$ signal appears in the range $171-173 \mathrm{ppm}$, in good agreement with the values described in the literature for iminic carbons in five- or six-member ring cyclometallated compounds derivatives of Schiff bases [49].

In the ${ }^{13} \mathrm{C}\left\{{ }^{1} \mathrm{H}\right\}$ NMR spectrum of [Pt(9AA)Cl(DMSO)], the couplings with ${ }^{195} \mathrm{Pt}$ nucleous are clearly observed. The values for the coupling constants (Supplementary Material available online at doi 10.1155/2007/98732.) are in good agreement with those described in the literature [50]. 
TABLE $1:{ }^{1} \mathrm{H}$ chemical shifts $(\mathrm{ppm})$ of 9 -aminoacridine $(9 \mathrm{AA})$ and the complexes $[\mathrm{Pd}(9 \mathrm{AA})(\mu-\mathrm{Cl})]_{2} \cdot 2 \mathrm{DMF},[\mathrm{Pd}(9 \mathrm{AA}) \mathrm{Cl}(\mathrm{L})]\left(\mathrm{L}=\mathrm{py}-d_{5}\right.$ or $\left.\mathrm{PPh}_{3}\right)$ and $[\mathrm{Pt}(9 \mathrm{AA}) \mathrm{Cl}(\mathrm{DMSO})]$. The numbering corresponds to the attached scheme and it will be the same along the spectroscopic studies.

\begin{tabular}{l|ccccc}
\hline & $9 \mathrm{AA}$ & {$[\mathrm{Pd}(9 \mathrm{AA})(\mu \mathrm{Cl})]_{2}{ }^{\&}$} & {$\left[\mathrm{Pd}(9 \mathrm{AA}) \mathrm{Cl}\left(\mathrm{py}-d_{5}\right)\right]^{\&, \#}$} & $\left.\left[\mathrm{Pd}(9 \mathrm{AA}) \mathrm{Cl}_{(\mathrm{PPh}}\right)\right]^{\&}$ & {$[\mathrm{Pt}(9 \mathrm{AA}) \mathrm{Cl}(\mathrm{DMSO})]^{\$}$} \\
\hline $\mathrm{H}^{1}$ & $8.40 \mathrm{~d}$ & - & - & - & - \\
$\mathrm{H}^{2}$ & $7.65 \mathrm{t}$ & $7.71 \mathrm{~d}$ & $5.89 \mathrm{~d}$ & $6.04 \mathrm{dd}$ & $7.95 \mathrm{~d}$ \\
$\mathrm{H}^{3}$ & $7.32 \mathrm{t}$ & $7.37 \mathrm{t}$ & $7.19 \mathrm{t}$ & $6.75 \mathrm{t}$ & $7.39 \mathrm{t}$ \\
$\mathrm{H}^{4}$ & $7.80 \mathrm{~d}$ & $7.14 \mathrm{~d}$ & $7.11 \mathrm{~d}$ & $6.88 \mathrm{~d}$ & $7.12 \mathrm{~d}$ \\
$\mathrm{H}^{5}$ & $7.80 \mathrm{~d}$ & $7.53 \mathrm{~d}$ & $7.59 \mathrm{~d}$ & $7.48^{*}$ & $7.62 \mathrm{~d}$ \\
$\mathrm{H}^{6}$ & $7.32 \mathrm{t}$ & $7.74 \mathrm{t}$ & $7.71 \mathrm{t}$ & $7.62^{*}$ & $7.76 \mathrm{t}$ \\
$\mathrm{H}^{7}$ & $7.65 \mathrm{t}$ & $7.23 \mathrm{t}$ & $7.25 \mathrm{t}$ & $7.22 \mathrm{t}$ & $7.34 \mathrm{t}$ \\
$\mathrm{H}^{8}$ & $8.40 \mathrm{~d}$ & $8.66 \mathrm{~d}$ & $8.60 \mathrm{~d}$ & $8.64 \mathrm{~d}$ & $8.66 \mathrm{~d}$ \\
$\mathrm{NH}^{9}$ & - & $8.94 \mathrm{~s}$ & $8.78 \mathrm{w}$ & $9.08 \mathrm{~d}$ & $8.58 \mathrm{w}$ \\
$\mathrm{NH}^{10}$ & - & $11.65 \mathrm{~s}$ & $11.68 \mathrm{w}$ & $11.42 \mathrm{~s}$ & $10.73 \mathrm{w}$ \\
\hline
\end{tabular}

s: singlet, d: doublet, t: triplet, w: wide, dd: doublet of doublets.

${ }^{\&}$ DMF signals were assigned at 7.99, 2.89 and $2.30 \mathrm{ppm}$.

\#Pyridine- $d_{5}$ signals were assigned at 7.40 and $7.80 \mathrm{ppm}$.

${ }^{\$}$ Recorded in acetone- $d_{6}$. The spectrum shows an additional singlet at $3.49 \mathrm{ppm}$ assigned to the protons of the $\mathrm{CH}_{3}$ groups of DMSO

$\left({ }^{3} J_{\mathrm{Pt}-\mathrm{H}(\mathrm{DMSO})}=21 \mathrm{~Hz}\right)$.<smiles></smiles>

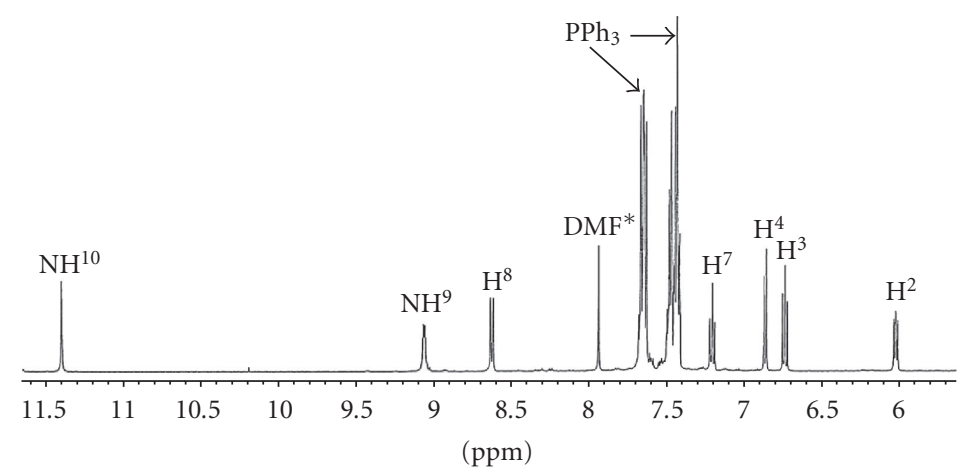

Figure 1: ${ }^{1} \mathrm{H}$ NMR spectrum (zone $\left.6-11.5 \mathrm{ppm}\right)$ of the complex $\left[\mathrm{Pd}(9 \mathrm{AA}) \mathrm{Cl}\left(\mathrm{PPh}_{3}\right)\right] .{ }^{*}$ Signal assigned to the DMF present in the precursor complex $[\mathrm{Pd}(9 \mathrm{AA})(\mu-\mathrm{Cl})]_{2} \cdot 2 \mathrm{DMF}$.

\section{5. ${ }^{31} P\left\{{ }^{1} H\right\} N M R$ spectra}

The ${ }^{31} \mathrm{P}\left\{{ }^{1} \mathrm{H}\right\}$ spectrum of $\left[\mathrm{Pd}(9 \mathrm{AA}) \mathrm{Cl}\left(\mathrm{PPh}_{3}\right)\right]$ (in DMSO$d_{6}$ ) shows a singlet at $40.77 \mathrm{ppm}$. The position and multiplicity of this signal is consistent with the data described in the literature for the five-membered rings palladacycles with $\sigma\left(\mathrm{Pd}-\mathrm{Csp}^{2}\right.$, aryl $)$ bonds $[43,51]$ of general formulae $\left[\mathrm{Pd}\left(\mathrm{C}^{\wedge} \mathrm{N}\right) \mathrm{X}\left(\mathrm{PPh}_{3}\right)\right]\left(\mathrm{X}=\mathrm{Cl}^{-}, \mathrm{Br}^{-}, \mathrm{I}^{-}\right.$or $\left.\mathrm{AcO}^{-}\right)$, where the phosphine is in trans to the iminic nitrogen.

\section{6. ${ }^{195}$ Pt NMR spectrum}

The complex $[\mathrm{Pt}(9 \mathrm{AA}) \mathrm{Cl}(\mathrm{DMSO})]$ has been also characterized by ${ }^{195} \mathrm{Pt}$ NMR (in acetone- $d_{6}$ ). The spectrum consists in a singlet at $-3756 \mathrm{ppm}$. The position of the signal [52] is similar to that described in the literature for mono- or bis-cycloplatinated compounds of formulae $\left[\mathrm{Pt}\left\{\left[\left(\eta^{5}-\mathrm{C}_{5} \mathrm{H}_{3}\right) \mathrm{CH}(\mathrm{R}) \mathrm{N}\left(\mathrm{CH}_{3}\right)_{2}\right] \mathrm{Fe}\left(\eta^{5}-\mathrm{C}_{5} \mathrm{H}_{5}\right)\right\} \mathrm{Cl}\right.$ (DMSO) $\left(-3763 \mathrm{ppm}\right.$ for $\mathrm{R}=\mathrm{H}$ and $-3899 \mathrm{ppm}$ for $\left.\mathrm{R}=\mathrm{CH}_{3}\right)$ [50] 


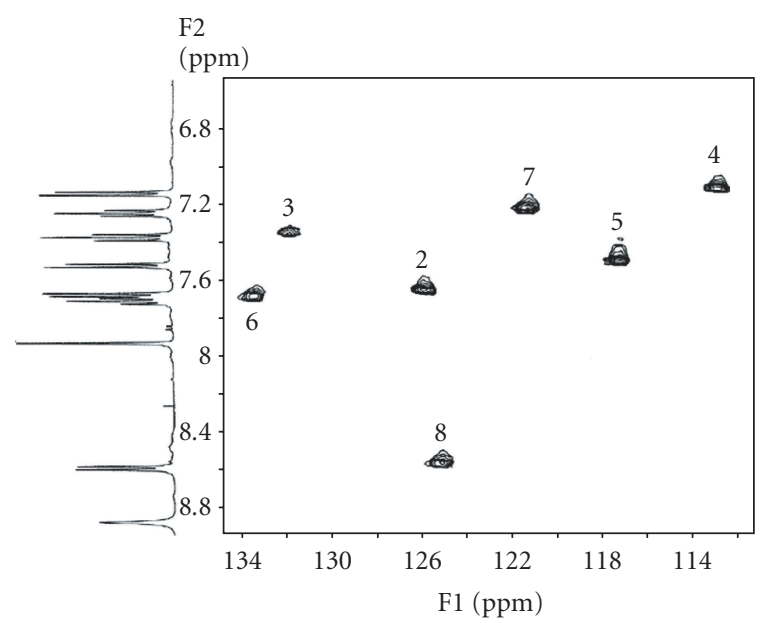

FIGURE 2: ${ }^{1} \mathrm{H}-{ }^{13} \mathrm{C}$ bidimensional heterocorrelated NMR spectrum of the compound $[\mathrm{Pd}(9 \mathrm{AA})(\mu-\mathrm{Cl})]_{2}$ (aromatic zone) where seven peaks of crossover are observed as indicator of the presence of a $\sigma\left(\mathrm{M}-\mathrm{Csp}^{2}\right.$, aryl $)$ bond.

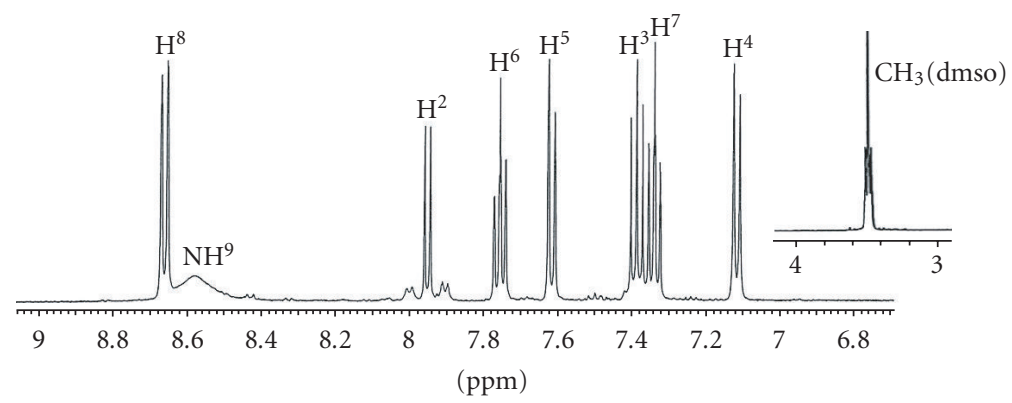

Figure 3: ${ }^{1} \mathrm{H}$ NMR spectrum of the complex [Pt(9AA)Cl(DMSO)].

TABLE 2: Crystal data and structure refinement for $[\mathrm{Pd}(9 \mathrm{AA})(\mu-\mathrm{Cl})]_{2} \cdot 2 \mathrm{DMF}$.

\begin{tabular}{l|l}
\hline Empirical formula & $\mathrm{C}_{26} \mathrm{H}_{30} \mathrm{Cl}_{2} \mathrm{~N}_{8} \mathrm{Pd}_{2}$ \\
Formula weight & 738.28 \\
Crystal size $(\mathrm{mm})$ & $0.1 \times 0.1 \times 0.2$ \\
Crystal system & Monoclinic \\
Space group & $\mathrm{P} 2{ }_{1} / \mathrm{c}$ \\
$\mathrm{a}, \mathrm{b}, \mathrm{c}\left({ }^{\prime}\right)$ & $\mathrm{a}=12.421(6) \mathrm{b}=9.538(5) \mathrm{c}=14.476(14)$ \\
$\alpha, \beta, \gamma\left(^{\circ}\right)$ & $\alpha=\gamma=90.0 \beta=109.07(5)$ \\
Volume $\left(\AA^{3}\right)$ & $1620.9(19)$ \\
$\mathrm{Z}$ & 1 \\
Density $($ calc. $)\left(\mathrm{Mg} \times \mathrm{m}^{-3}\right)$ & 0.756 \\
Absorption coefficient $\left(\mathrm{mm}^{-1}\right)$ & 0.651 \\
$\mathrm{~F}(000)$ & 368 \\
Temperature $(\mathrm{K})$ & $293(2)$ \\
Wavelength $\left(^{\prime}\right)$ & 0.71069 \\
$\theta$ range $\left(^{\circ}\right)$ & $2.60-29.97$ \\
Reflexions collected & 4911 \\
Unique reflexions & $4715[\mathrm{R}(\mathrm{int})=0.0182]$ \\
Data/restraints/parameters & $4665 / 0 / 200$ \\
Goodness-of-fit on $\mathrm{F}^{2}$ & 1.007 \\
Final R & $\mathrm{R} 1=0.0336, \mathrm{wR} 1=0.0895$ \\
$\mathrm{R}($ all data $)$ & $\mathrm{R} 1=0.0507, \mathrm{wR} 2=0.0968$ \\
\hline
\end{tabular}


and $\left[\mathrm{Pt}_{2}\left[\left\{\eta^{5}-\mathrm{C}_{5} \mathrm{H}_{3} \mathrm{CH}(\mathrm{R}) \mathrm{N}\left(\mathrm{CH}_{3}\right)_{2}\right\}_{2} \mathrm{Fe}\right] \mathrm{Cl}_{2}(\mathrm{DMSO})_{2}\right](\mathrm{R}=$ $\mathrm{H}$ or $\mathrm{CH}_{3}$ ) [53] where the platinum(II) is surrounded by a $\mathrm{CNSCl}$ coordination environment and the ligand DMSO is in trans position to the nitrogen atom bound to the metal ion.

\subsection{Crystal structure of $[P d(9 A A)(\mu-C l)]_{2} \cdot 2 D M F$}

The main crystallographic data and structure refinement are collected in Table 2. The molecular structure of the complex with the numbering of the atoms is shown in Figure 4. The bond distances and angles are included in Supplementary material. The structure consists in molecules of $[\mathrm{Pd}(9 \mathrm{AA})(\mu-$ $\mathrm{Cl})]_{2}$ and DMF in a molar relationship 1:2.

In the $[\mathrm{Pd}(9 \mathrm{AA})(\mu-\mathrm{Cl})]_{2}$ molecules, the palladium atoms $\left\{\operatorname{Pd}(1)\right.$ and $\left.\operatorname{Pd}\left(1^{\#}\right)\right\}$ are bound to two lligands $\{\mathrm{Cl}(2)$ and $\left.\mathrm{Cl}\left(2^{\#}\right)\right\}$ in cis position which act as bridges between the two metal centres. The two coordination sites are occupied by the exocyclic nitrogen $\{\mathrm{N}(9)\}$ and the carbon atom $\mathrm{C}(1)$ from the 9-aminoacridine ligand, confirming the proposal of the formation of a $\sigma\left(\mathrm{Pd}-\mathrm{Csp}^{2}\right.$, aryl) bond, and the bidentate and monoanionic ligand condition of the 9-aminoacridine.

The molecule could be viewed as the combination of fragments " $[\mathrm{Pd}(9 \mathrm{AA})(\mu-\mathrm{Cl})]$ " sharing chlorine bridges to form a " $\mathrm{Pd}(\mu-\mathrm{Cl})_{2} \mathrm{Pd}$ " unit. The relative position of the metalated ligands is in trans, and the environment of palladium atom is a slightly distorted square plannar. ${ }^{1}$

The bond distance $\mathrm{Pd}-\mathrm{N}\{2.023(3) \AA\}$ is similar to those described in the literature for five-membered ring palladacycles derivatives of organic ligands with $>\mathrm{C}=\mathrm{N}-$ groups, such as imines [54], oximes [55], or hydrazones [56]. The bond length for $(\mathrm{Pd}-\mathrm{C})\{1.987(2) \AA\}$ is in good agreement with those expected for the bonds between palladium(II) and a $\mathrm{Csp}^{2}$, aryl (these bond distances are typically in the range $1.98 \AA$ and $2.10 \AA)[43,56-60]$.

The bond angles involving palladium atom between $82.72(11)^{\circ}\{\mathrm{C}(1)-\mathrm{Pd}(1)-\mathrm{N}(9)\}$ and $94.31(9)^{\circ}\{\mathrm{Cl}(2)-\mathrm{Pd}(1)-$ $\left.\mathrm{Cl}\left(2^{\#}\right)\right\}$ are in good agreement with those described in the literature for five-membered ring cyclopalladated dinuclear complexes $\left[\mathrm{Pd}\left(\mathrm{C}^{\wedge} \mathrm{N}\right)(\mu-\mathrm{X})\right]_{2}$.

Each of the two halves of the molecule has a fivemembered metallocycle formed by $\mathrm{Pd}(1), \mathrm{N}(9), \mathrm{C}(9), \mathrm{C}(12)$, and $\mathrm{C}(13)$ atoms, which is practically planar ${ }^{2}$ and forms a $3.3^{\circ}$ angle with the coordination plane of the metal.

The units " $\mathrm{Pd}(\mu-\mathrm{Cl})_{2} \mathrm{Pd}$ " are asymmetric, as indicated by the value of the bond distances $\mathrm{Pd}(1)-\mathrm{Cl}(2): 2.4741(13) \AA$ and $\operatorname{Pd}(1)-\mathrm{Cl}\left(2^{\#}\right): 2.352(2) \AA$. This result is consistent with the structural data obtained for dimeric cyclopalladated

\footnotetext{
${ }^{1}$ The equation of the plane defined by the atoms $\mathrm{Cl}(2), \mathrm{Cl}\left(2^{\#}\right), \mathrm{N}(9)$, and $\mathrm{C}(1)$ is $(-0.1236) \mathrm{XO}+(0.9015) \mathrm{YO}+(0.4146) \mathrm{ZO}=4.2986$. The deviations related to the main plane are $\mathrm{Cl}(2):-0.035, \mathrm{Cl}\left(2^{\#}\right): 0.037, \mathrm{~N}(9)$ : 0.045 , and C(1): $-0.047 \AA$.

2 The equation of the plane defined by the atoms $\mathrm{Pd}(1), \mathrm{N}(9), \mathrm{C}(9), \mathrm{C}(1)$, and $\mathrm{C}(13)$ is $(-0.1700) \mathrm{XO}+(0.9087) \mathrm{YO}+(0.3808) \mathrm{ZO}=4.2078$. The deviations related to the main plane are $\mathrm{Pd}(1):-0.019, \mathrm{~N}(9)$ : $-0.023, \mathrm{C}(9)$ : 0.015, C(1): -0.019 , and C(13): $0.008 \AA$.
}

complexes with chlorine bridges and trans configuration of the two palladate groups of general formula $\left[\mathrm{Pd}\left(\mathrm{C}^{\wedge} \mathrm{N}\right)(\mu\right.$ $\mathrm{Cl})]_{2}$. This is a consequence of the different influence of the atoms in trans position the metallated carbon $(\mathrm{C} 1)$ and the nitrogen $\mathrm{N}(9)$ \} [43].

The planar unit " $\mathrm{Pd}(\mu-\mathrm{Cl})_{2} \mathrm{Pd} " 3$ forms a $4.9^{\circ}$ angle with the metallocycle (see Figure 5) and it has a rhomboidal shape. The distance between the two palladium atoms, 3.479(1) $\AA$, is too large to consider the existence of significant Pd ...P Pd interactions.

The bond angle $\mathrm{Cl}(2)-\mathrm{Pd}(1)-\mathrm{Cl}\left(2^{\#}\right)$ is similar to those described for compounds of general formula trans$\left[\mathrm{Pd}\left(\mathrm{C}^{\wedge} \mathrm{N}\right)(\mu-\mathrm{Cl})\right]_{2}$ containing five-membered metallocycles [61].

The tricyclic system $[6,6,6]$ of the aromatic ligand is practically planar ${ }^{4}$ and it forms a $2.4^{\circ}$ angle with the palladacycle. This is in contrast with what occurs in other reported structures [22] where the 9-aminoacridine is bound to the metal through its exocyclic nitrogen is also present as imino tautomer and a folding of the side rings with respect to the $\mathrm{N}(10)-\mathrm{C}(9)$ vector was found. One of the most significant structural features of the 9-aminoacridine group in the compound $[\mathrm{Pd}(9 \mathrm{AA})(\mu-\mathrm{Cl})]_{2}$ is the bond length $\mathrm{N}(9)-\mathrm{C}(9), 1.312(3) \AA$, which is appreciably smaller than the expected value for a $\sigma\left(\mathrm{Csp}^{2}-\mathrm{Nsp}^{3}\right)$ bond and very similar to those described in the literature for complexes containing the functional group $>\mathrm{C}=\mathrm{N}-$ (see footnote 1 ) and also for the platinum compound $[\mathrm{Pt}(\mathrm{L}) \mathrm{Cl}]$, where $\mathrm{L}=1$-nitro9-[\{2-(dimethylamino)ethyl $\}$ amino $]$ acridine [22] with the presence of the tautomeric form imino.

Moreover, the bond distances $\mathrm{N}(10)-\mathrm{C}(11)$ $\{1.399(4) \AA\}$ and $\mathrm{N}(10)-\mathrm{C}(14) \quad\{1.379(3) \AA\}$ and the bond angle $\mathrm{C}(11)-\mathrm{N}(10)-\mathrm{C}(14) \quad\left\{122.3(2)^{\circ}\right\}$ in the complex $[\mathrm{Pd}(9 \mathrm{AA})(\mu-\mathrm{Cl})]_{2}$ are higher than expected for an amino form and very similar to those found for the cited platinum complex [22]. These observations allow to conclude that in the complex $[\mathrm{Pd}(9 \mathrm{AA})(\mu-\mathrm{Cl})]_{2}$ the ligand is present in the imino form and that the functional group $>\mathrm{C}=\mathrm{N}-$ is included in the five-membered metallocycle.

The bond distances and angles found for the two molecules of dimethylformamide present in the crystal structure of $[\mathrm{Pd}(9 \mathrm{AA})(\mu-\mathrm{Cl})]_{2} \cdot 2 \mathrm{DMF}$ are similar to those described in the literature for complexes containing DMF crystallization molecules. The distance between the oxygen atom of DMF and the hydrogen bound to the endocyclic nitrogen, $\mathrm{N}(10)$, of the complex $[\mathrm{Pd}(9 \mathrm{AA})(\mu-\mathrm{Cl})]_{2}\{\mathrm{O} \cdots \mathrm{H}-\mathrm{N}(10)=$ $2.857(4) \AA$ s suggests the existence of intermolecular hydrogen interactions. The strong downfield shift observed in the proton NMR spectrum assigned to the $\mathrm{H}^{10}(\delta=11.65 \mathrm{ppm})$, could confirm the existence of these interactions in solution.

\footnotetext{
3 The equation of the plane defined by the four atoms involved in the unit " $\mathrm{Pd}(\mu-\mathrm{Cl})_{2} \mathrm{Pd}$ " is $(-0.1050) \mathrm{XO}+(0.8943) \mathrm{YO}+(0.4350) \mathrm{ZO}=4.2649$.

4 The equation of the plane defined by the 14 atoms involved in the tricycle system of the acridine molecule is $(-0.2109) \mathrm{XO}+(0.9051) \mathrm{YO}+$ $(0.3693) \mathrm{ZO}=4.0107$.
} 


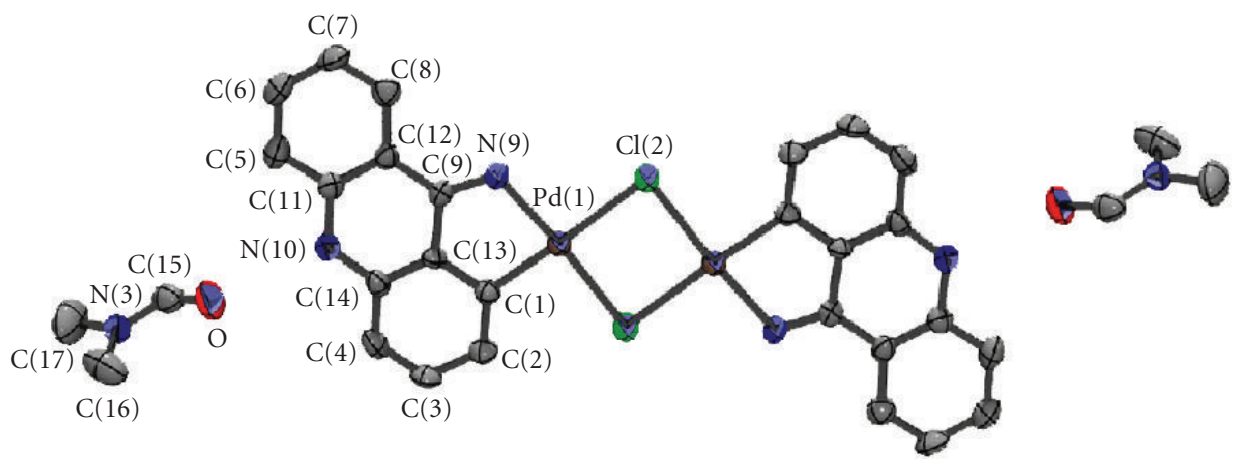

Figure 4: Molecular structure of the complex $[\mathrm{Pd}(9 \mathrm{AA})(\mu-\mathrm{Cl})]_{2} \cdot 2 \mathrm{DMF}$.

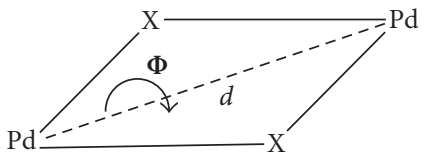

(a)

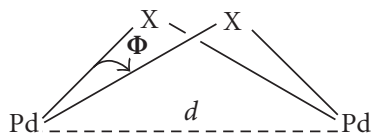

(b)
Figure 5: Geometry of the fragment " $\mathrm{Pd}(\mu-\mathrm{X})_{2} \mathrm{Pd}$ " and dependence of the distance Pd ... Pd with the angle $\boldsymbol{\Phi}$.

\section{BIOLOGICAL STUDIES}

\subsection{Circular Dichroism}

The molecules of 9-aminoacridine (9AA) and complexes $[\mathrm{Pd}(9 \mathrm{AA})(\mu-\mathrm{Cl})]_{2}$ and $[\mathrm{Pt}(9 \mathrm{AA}) \mathrm{Cl}(\mathrm{DMSO})]$ originate modifications in the spectrum of Calf Thymus DNA at different values of $\left(r_{i}\right)$ selected as it is shown in Figure 6. The wavelengths, corresponding to the maximum and minimum values of the ellipticity, are collected in Table 3.

The complexes $[\mathrm{Pd}(9 \mathrm{AA})(\mu-\mathrm{Cl})]_{2}$ and $[\mathrm{Pt}(9 \mathrm{AA}) \mathrm{Cl}-$ (DMSO)] can interact with the DNA, in principle, by intercalation of the ligand and/or forming a covalent bond through the metal ion.

Looking at the spectrum recorded for the CT-DNA incubated with the complex $[\mathrm{Pd}(9 \mathrm{AA})(\mu-\mathrm{Cl})]_{2}$ (see Figure 6(b)), a very strong decreasing of the ellipticity of both, the positive and negative bands, and a batochromic shift of the bands can be observed. This is the opposite effect to that observed for the free 9-aminoacridine (9AA) (see Figure 6(a)). In the case of the platinum compound [Pt(9AA)Cl(DMSO)] (see Figure 6(c)), the change in the negative band is similar to that of the palladium compound but the maximum is much less intense.

On the other hand, the amounts of metal incorporated to the DNA are much higher for the palladium compound than for the platinum compound (see Table 3 ). Moreover, the complex $[\mathrm{Pd}(9 \mathrm{AA})(\mu-\mathrm{Cl})]_{2}$ gives a percentage of metal incorporation higher than cisplatin at the molar relationships $\left(\mathrm{r}_{\mathrm{i}}\right)$ used. The small percentage of platinum incorporated to DNA for $[\mathrm{Pt}(9 \mathrm{AA}) \mathrm{Cl}(\mathrm{DMSO})]$ may be conditioned by the different labilization kinetic of 9-aminoacridine and chlorine ions and/or the fact that the compound $[\mathrm{Pt}(9 \mathrm{AA}) \mathrm{Cl}(\mathrm{DMSO})]$ contains only a hydrolysable chlorine and the most probable adduct that could be formed with DNA would be monofunctional.

In conclusion, the 9-aminoacridine behaves as a classical intercalator but the palladium and platinum complexes produce changes of different nature, probably due to the formation of a covalent bond or the occurrence of both interactions, covalent, and intercalation, simultaneously.

\subsection{Electrophoretic mobility}

In Figure 7, the electrophoretic mobility pattern of cisplatin, 9-aminoacridine and the complex $[\mathrm{Pd}(9 \mathrm{AA})(\mu-\mathrm{Cl})]_{2}$ are shown. At low values of $\left(\mathrm{r}_{\mathrm{i}}\right)$, a decreasing of the CCC form mobility for the free 9-aminoacridine molecule (lane C) can be observed. However, at $\left(r_{i}\right)=0.5$, the mobility increases. This behavior is similar to that observed for cisplatin at higher concentrations than the ones used in this study. The intercalation interaction usually causes a higher degree of supercoiling than the one produced by a covalent cis-bifunctional binding [62] .

On the other hand, the electrophoretic behavior of pBR322, incubated with the compound $[\mathrm{Pd}(9 \mathrm{AA})(\mu-\mathrm{Cl})]_{2}$ (Figure 7, lane B), is close to that of cisplatin (Figure 7, lane A) which seems to indicate that the interaction of this compound is not only intercalative. This seems to agree with the results obtained from the circular dicroism study described in the previous section.

Finally, the complex $[\mathrm{Pt}(9 \mathrm{AA}) \mathrm{Cl}(\mathrm{DMSO})]$ (Figure 8, lane B) causes slight modifications in the electrophoretic mobility of the OC while the CCC form retards, which suggests that the uncoiling of the helix occurs on a minor degree. It is possible that, in addition to the intercalation, a monofunctional covalent binding could be established. This result would agree with the published results for the complex $[\mathrm{PtCl}($ dien $)] \mathrm{Cl}$, which uncoils the helix about $6^{\circ}$, half of the value expected for a cis bifunctional binding as int the values described for cisplatin [62].

\subsection{Atomic force microscopy}

AFM images of the plasmid pBR322 DNA incubated with the compounds $[\mathrm{Pd}(9 \mathrm{AA})(\mu-\mathrm{Cl})]_{2}$ and $\left[\mathrm{Pd}(9 \mathrm{AA}) \mathrm{Cl}\left(\mathrm{PPh}_{3}\right)\right]$ for 


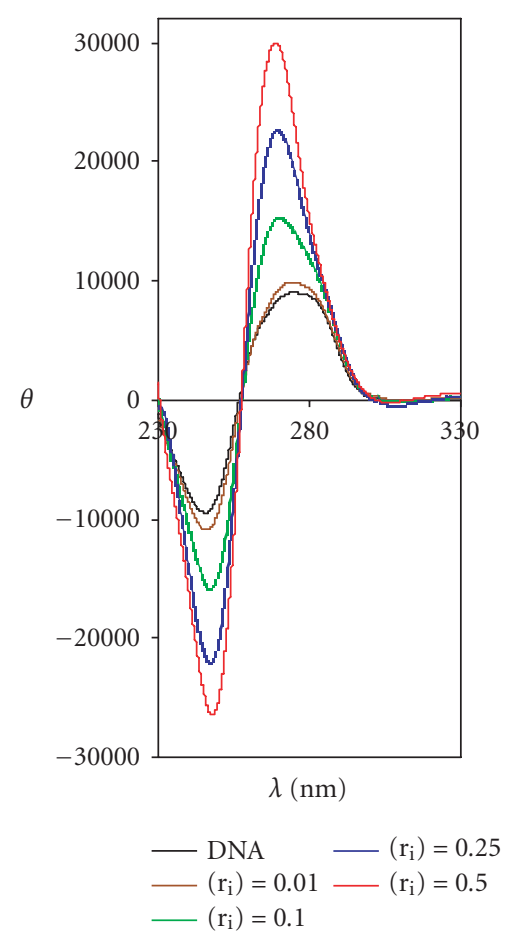

(a)
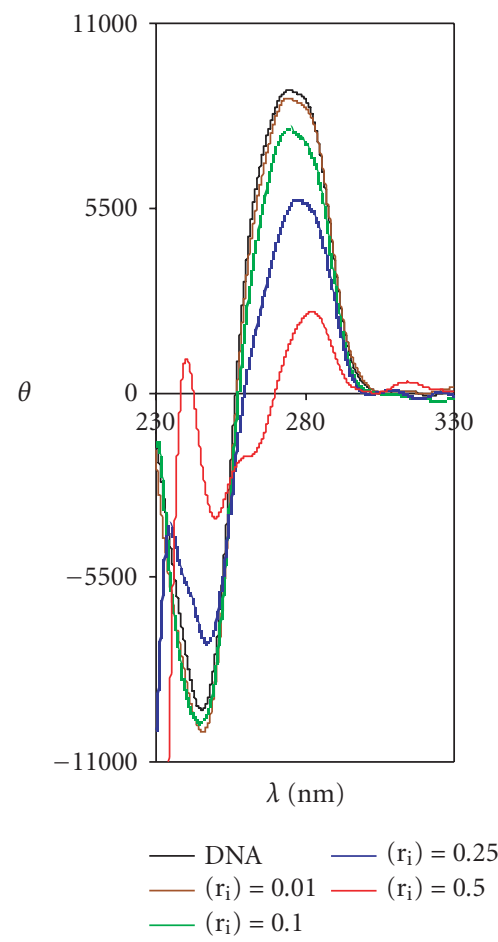

(b)

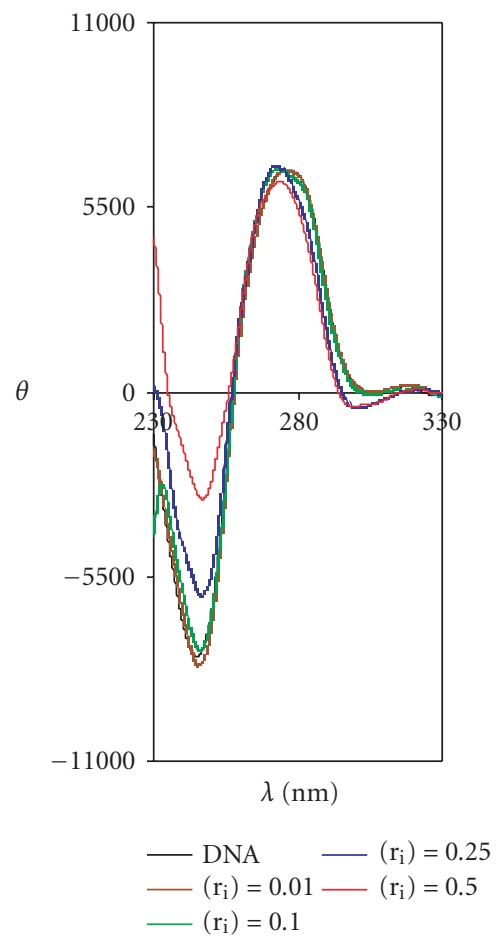

(c)

FIgUre 6: DC spectra of Calf Thymus DNA incubated with (a) 9-aminoacridine (9AA), (b) $\left[\mathrm{Pd}(9 \mathrm{AA})(\mu \text {-Cl) }]_{2}\right.$, and (c) $[\mathrm{Pt}(9 \mathrm{AA}) \mathrm{Cl}(\mathrm{DMSO})]$.

TABLE 3: Ellipticity values and wavelenghts (maximum and minimum) in CD spectra of Calf Thymus DNA incubated with 9-aminoacridine (9AA) and its palladium and platinum complexes.

\begin{tabular}{|c|c|c|c|c|c|c|}
\hline Compound & $\mathrm{r}_{\mathrm{i}}$ & $\theta_{\max }^{(a)}$ & $\lambda_{\max }^{(b)}$ & $\theta_{\min }^{(a)}$ & $\lambda_{\min }^{(b)}$ & $\%$ uptaken metal \\
\hline $\mathrm{DNA}^{(\mathrm{c})}$ & - & 9.0 & 275.0 & -9.5 & 245.5 & - \\
\hline \multirow[t]{4}{*}{$9 \mathrm{AA}$} & 0.01 & 9.8 & 274.1 & -10.9 & 246.0 & - \\
\hline & 0.10 & 15.3 & 270.0 & -15.9 & 247.0 & - \\
\hline & 0.25 & 22.7 & 269.2 & -22.1 & 247.0 & - \\
\hline & 0.50 & 30.0 & 268.8 & -26.5 & 247.8 & - \\
\hline \multirow[t]{4}{*}[\mathrm{Pd}(9\mathrm{AA})(\mu-\mathrm{Cl})]{$_{2}$} & 0.01 & 8.8 & 274.5 & -10.1 & 245.8 & 62.24 \\
\hline & 0.10 & 7.8 & 274.4 & -9.8 & 244.8 & 51.82 \\
\hline & 0.25 & 5.7 & 277.6 & -7.4 & 247.0 & 50.48 \\
\hline & 0.50 & 2.4 & 282.4 & -3.7 & 250.0 & 52.67 \\
\hline $\mathrm{DNA}^{(\mathrm{d})}$ & - & 6.6 & 276.0 & -7.9 & 245.0 & - \\
\hline \multirow[t]{4}{*}[\mathrm{Pt}(9\mathrm{AA})\mathrm{Cl}(\mathrm{DMSO})]{} & 0.01 & 6.6 & 276.0 & -8.1 & 245.6 & 9.72 \\
\hline & 0.10 & 6.7 & 272.8 & -7.7 & 245.8 & 7.43 \\
\hline & 0.25 & 6.7 & 272.5 & -6.0 & 246.5 & 6.21 \\
\hline & 0.50 & 6.2 & 273.8 & -3.2 & 247.1 & 5.44 \\
\hline
\end{tabular}

(a) degrees $\times \mathrm{cm}^{2} \times \mathrm{dmol}^{-1} \times 10^{3}$;

(b) $\mathrm{nm}$;

(c) $6.49 \times 10^{-5} \mathrm{~mol} \times 1^{-1}$;

(d) $6.10 \times 10^{-5} \mathrm{~mol} \times 1^{-1}$. 


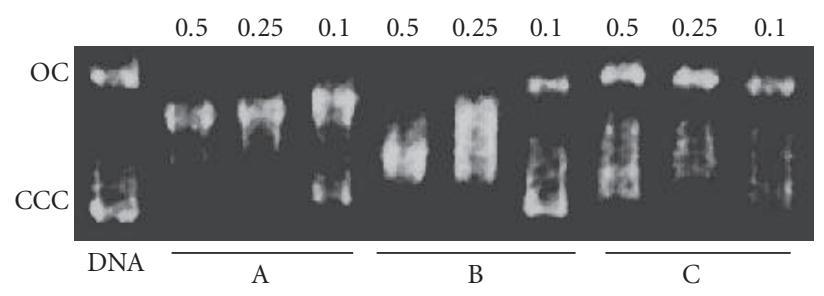

FIGURE 7: Eletrophoretic mobility pattern of pBR322 plasmid DNA incubated with the complexes: lane A: cisplatin; lane B: $[\mathrm{Pd}(9 \mathrm{AA})(\mu-\mathrm{Cl})]_{2}$; lane C: 9AA.

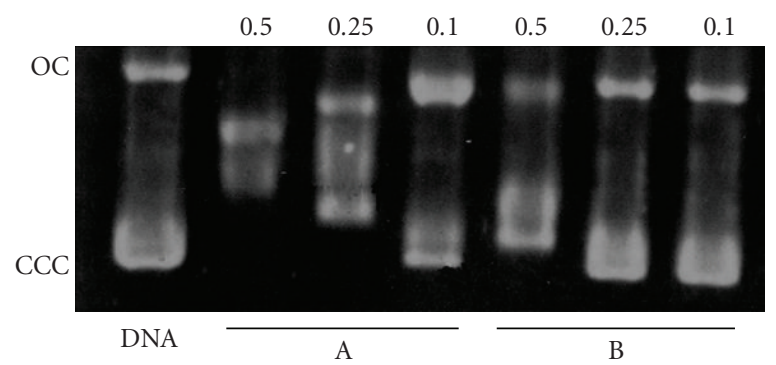

FIGURE 8: Electrophoretic mobility pattern of pBR322 plasmid DNA incubated with the complexes: lane A: cisplatin; lane B: [Pt(9AA)Cl(DMSO)].

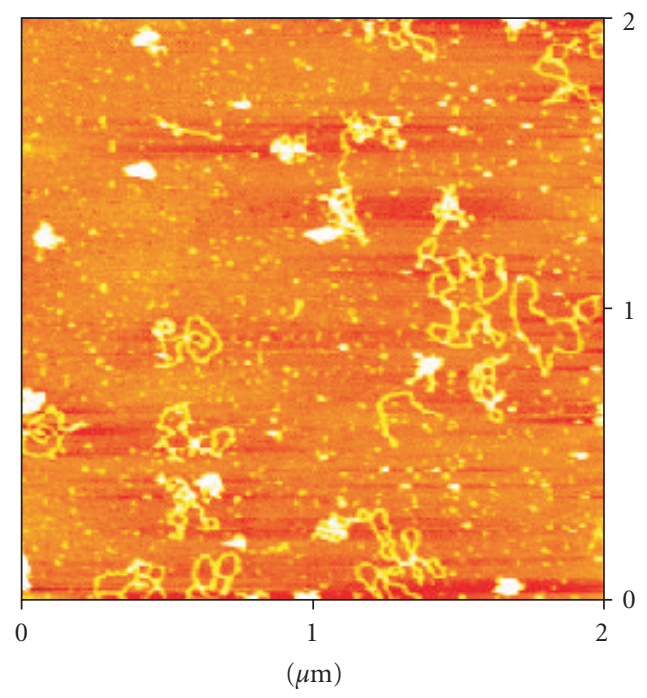

FIgURE 9: AFM image of the pBR322 plasmid DNA incubated with the complex $[\mathrm{Pd}(9 \mathrm{AA})(\mu-\mathrm{Cl})]_{2}$.

5 hours and $37^{\circ} \mathrm{C}$ are presented in Figures 9 and 10, respectively.

In all the images supercoiled forms of the plasmid DNA can be observed. These modifications are likely to correspond to the strong effect of intercalation of the 9aminoacridine ligand.

Supercoiling in the plasmid DNA tertiary structure has been observed before for other classic intercalators such as ethydium bromide and planar heterocycles $[63,64]$.

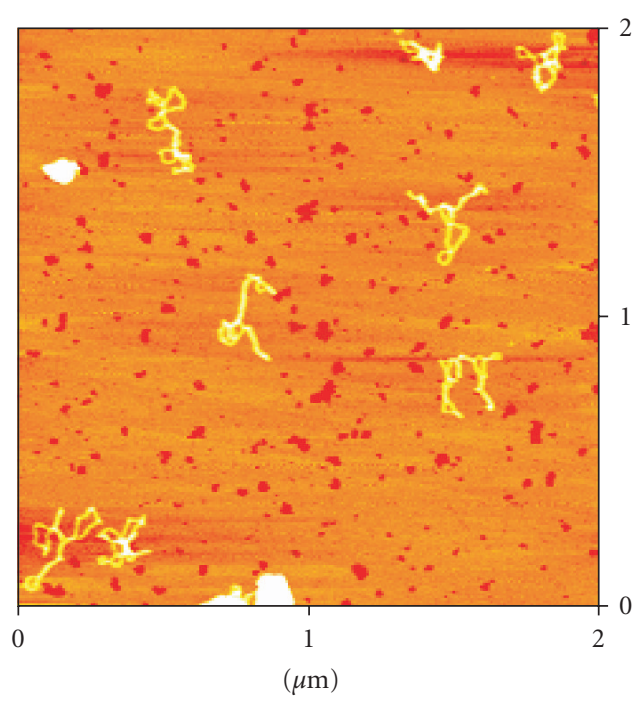

(a)

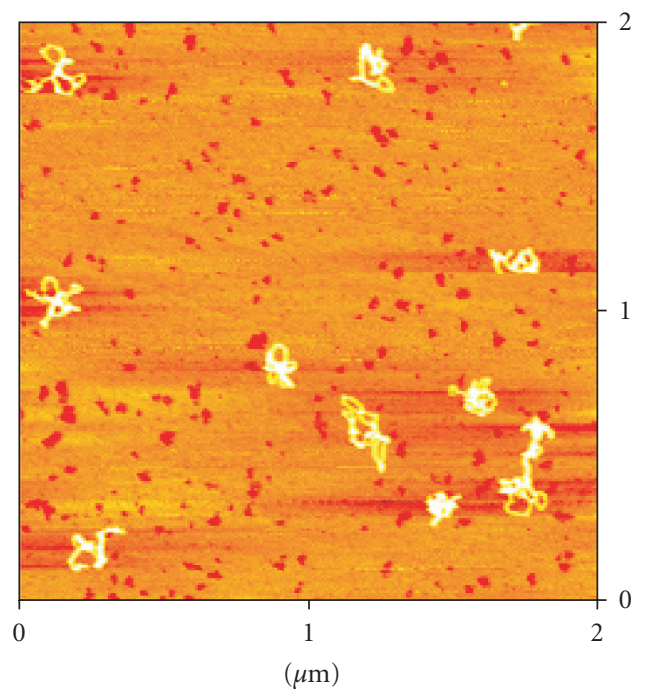

(b)

Figure 10: Two AFM images corresponding to pBR322 plasmid DNA incubated with the complex $\left[\mathrm{Pd}(9 \mathrm{AA}) \mathrm{Cl}\left(\mathrm{PPh}_{3}\right)\right]$.

In the case of the complex $\left[\mathrm{Pd}(9 \mathrm{AA}) \mathrm{Cl}\left(\mathrm{PPh}_{3}\right)\right]$, additional interaction, probably due to the formation of covalent bond with the $\mathrm{N}$ atom of the purine bases, originates deeper changes in the structure of the plasmid.

\subsection{Antiproliferative assays}

The "in vitro" growth inhibitory effect of the 9-aminoacridine and its palladium complex $[\mathrm{Pd}(9 \mathrm{AA})(\mu-\mathrm{Cl})]_{2}$ were evaluated in three tumor cell lines: MCF-7 breast cancer cell line, DU-145 prostate cancer cell line, and HeLa cervix cancer cell line.

In Table 4 , the $\mathrm{IC}_{50}$ values for the two compounds against the three tumor cell lines are collected. The 9-aminoacridine again presents low $\mathrm{IC}_{50}$ values against the tumor cell lines 
TABLE 4: $\mathrm{IC}_{50}$ values $(\mu \mathrm{M})$ for the compounds studied against the tumor cell lines MCF-7, DU-145, and HeLa.

\begin{tabular}{l|ccc}
\hline Compound & MCF-7 & DU-145 & HeLa \\
\hline cisplatin & 9.4 & 3.7 & 22.2 \\
$9 \mathrm{AA}$ & 4.9 & 11.9 & 22.2 \\
{$[\mathrm{Pd}(9 \mathrm{AA})(\mu-\mathrm{Cl})]_{2}$} & 38.1 & 32.6 & $>50$ \\
\hline
\end{tabular}

assayed. These results suggest a direct correlation with the conclusions drawn from the studies of interaction with DNA in previous sections. Many other compounds related to acridines have demonstrated intercalation in DNA and antiproliferative behavior [65]. Although the $[\mathrm{Pd}(9 \mathrm{AA})(\mu-\mathrm{Cl})]_{2}$ derivative shows higher $\mathrm{IC}_{50}$ values than cisplatin, the $\mathrm{pa}$ rameters are low enough to merit consideration in further biochemical studies.

\section{ACKNOWLEDGMENTS}

This work was supported by Grants BQU2002-00601 and CTQ2005-01834BQU (Ministerio de Ciencia y Tecnología, MCYT, Spain). X. Riera wishes to thank the University of Barcelona for a grant. We thank Dr. M. Capdevila (cell culture and antiproliferative assays facility).

\section{REFERENCES}

[1] N. Farrell, Transition Metal Complexes as Drugs and Chemotherapeutic Agents, Kluwer Academic Publishers, Dordrecht, The Netherlands, 1989.

[2] L. S. Lerman, "Structural considerations in the interaction of DNA and acridines," Journal of Molecular Biology, vol. 3, pp. 18-30, 1961.

[3] L. S. Lerman, "Acridine mutagens and DNA structure," Journal of Cellular and Comparative Physiology, vol. 64, no. S1, pp. 1$18,1964$.

[4] W. A. Denny, B. C. Baguley, B. F. Cain, and M. J. Waring, "Antitumor acridines," in Molecular Aspects of Anti-Cancer Drug Action, M. J. Waring and S. Neidle, Eds., vol. 3 of Topics in Molecular \& Structural Biology, pp. 1-4, Verlag Chemie, Weinheim, Germany, 1983.

[5] C. Radzikowski, A. Ledóchowski, M. Hrabowska, et al., "A search for antitumor compounds. V. Biologic studies. Antitumor properties of 41 new acridine derivatives," Archivum Immunologiae et Therapiae Experimentalis, vol. 17, no. 1, pp. 8698, 1969.

[6] C. Korth, B. C. H. May, F. E. Cohen, and S. B. Prusiner, "Acridine and phenothiazine derivatives as pharmacotherapeutics for prion disease," Proceedings of the National Academy of Sciences of the United States of America, vol. 98, no. 17, pp. 9836$9841,2001$.

[7] W. A. Denny and B. C. Baguley, "Acridine-based anticancer drugs," in Molecular Aspects of Drug-DNA Interactions, M. J. Waring and S. Neidle, Eds., vol. 2, MacMillan, London, UK, 1994.
[8] M. Wirth, O. Buchardt, T. Koch, P. E. Nielsen, and B. Nordén, "Interactions between DNA and mono-, bis-, tris-, tetrakis, and hexakis(aminoacridines). A linear and circular dichroism, electric orientation relaxation, viscometry, and equilibrium study," Journal of the American Chemical Society, vol. 110, no. 3, pp. 932-939, 1988.

[9] E. S. Canellakis, Y. H. Shaw, W. E. Hanners, and R. A. Schwartz, "Diacridines: bifunctional intercalators-I: chemistry, physical chemistry and growth inhibitory properties," Biochimica et Biophysica Acta, vol. 418, no. 3, pp. 277-289, 1976.

[10] A. Lorente, M. Fernández-Saiz, J.-M. Lehn, and J.-P. Vigneron, "Cyclo-bis- and cyclo-tris-intercalands based on acridine subunits," Tetrahedron Letters, vol. 36, no. 45, pp. 8279-8282, 1995.

[11] B. E. Bowler, L. S. Hollis, and S. J. Lippard, "Synthesis and DNA binding and photonicking properties of acridine orange linked by a polymethylene tether to $(1,2-$ diaminoethane)dichloroplatinum(II)," Journal of the American Chemical Society, vol. 106, no. 20, pp. 6102-6104, 1984.

[12] B. E. Bowler, K. J. Ahmed, W. I. Sundquist, L. S. Hollis, E. E. Whang, and S. J. Lippard, "Synthesis, characterization, and DNA-binding properties of (1,2-diaminoethane)platinum(II) complexes linked to the DNA intercalator acridine orange by trimethylene and hexamethylene chains," Journal of the American Chemical Society, vol. 111, no. 4, pp. 1299-1306, 1989.

[13] J. Rak, J. Błaźejowski, and R. J. Zauhar, "Theoretical studies on the prototropic tautomerism, structure, and features of acridine and 9-acridinamine free bases and their protonated forms," Journal of Organic Chemistry, vol. 57, no. 13, pp. 37203725, 1992.

[14] J. Rak and J. Błaźejowski, "Experimental and INDO CI calculations of the electronic absorption spectra of acridine and 9-acridinamine free bases and their protonated forms with regard to tautomeric phenomena," Journal of Photochemistry and Photobiology A, vol. 67, no. 3, pp. 287-299, 1992.

[15] J. Rak, P. Skurski, M. Gutowski, L. Jóźwiak, and J. Błaźejowski, "Hartree-fock and density functional methods and IR and NMR spectroscopies in the examination of tautomerism and features of neutral 9-acridinamine in gaseous and condensed media," Journal of Physical Chemistry A, vol. 101, no. 3, pp. 283-292, 1997.

[16] T. D. Sakore, B. S. Reddy, and H. M. Sobell, "Visualization of drug-nucleic acid interactions at atomic resolution-IV: structure of an aminoacridine-dinucleoside monophosphate crystalline complex, 9-aminoacridine-5-iodocytidylyl $3^{\prime}-5^{\prime}$ guanosine," Journal of Molecular Biology, vol. 135, no. 4, pp. 763-785, 1979.

[17] S. A. Woodson and D. M. Crothers, "Binding of 9aminoacridine to bulged-base DNA oligomers from a frameshift hot spot," Biochemistry, vol. 27, no. 25, pp. 8904-8914, 1988.

[18] F. E. Hahn, "Berberine," in Antibiotics, Mechanism of Action of Antimicrobial and Antitumor Agents, J. W. Corcovan and F. E. Hahn, Eds., vol. 3, pp. 577-584, Springer, New York, NY, USA, 1975.

[19] G. E. Bass, D. R. Hudson, J. E. Parker, and W. P. Purcell, "Mechanism of antimalarial activity of chloroquine analogs from quantitative structure-activity studies. Free energy related model," Journal of Medicinal Chemistry, vol. 14, no. 4, pp. 275-283, 1971.

[20] Y. Mikata, M. Yokoyama, K. Mogami, et al., "Intercalatorlinked cisplatin: synthesis and antitumor activity of cisdichloroplatinum(II) complexes connected to acridine and 
phenylquinolines by one methylene chain," Inorganica Chimica Acta, vol. 279, no. 1, pp. 51-57, 1998.

[21] W. I. Sundquist, D. P. Bancroft, and S. J. Lippard, "Synthesis, characterization, and biological activity of cisdiammineplatinum(II) complexes of the DNA intercalators 9-aminoacridine and chloroquine," Journal of the American Chemical Society, vol. 112, no. 4, pp. 1590-1596, 1990.

[22] E. Ceci, R. Cini, J. Konopa, L. Maresca, and G. Natile, "Coordination and peri-carbon metalation of 1-nitro-9-[(2aminoethyl)amino] acridines toward platinum(II). evidences for hydrogen bonding between endocyclic $\mathrm{N}(10) \mathrm{H}$ and chloride ion," Inorganic Chemistry, vol. 35, no. 4, pp. 876-882, 1996.

[23] L. Maresca, C. Pacifico, M. C. Pappadopoli, and G. Natile, "Endocyclic versus exocyclic N-coordination to platinum(II) of some nitro-9-[(2-dialkylaminoethyl)amino]acridines," Inorganica Chimica Acta, vol. 304, no. 2, pp. 274-282, 2000.

[24] M. Carlone, N. G. Di Masi, L. Maresca, N. Margiotta, and G. Natile, "Role of metal ions and hydrogen bond acceptors in the tautomeric equilibrium of nitro-9[(alkylamino)amino]acridine drugs," Bioinorganic Chemistry and Applications, vol. 2, no. 1-2, pp. 93-104, 2004.

[25] M. D. Temple, W. D. McFadyen, R. J. Holmes, W. A. Denny, and V. Murray, "Interaction of cisplatin and DNA-targeted 9aminoacridine platinum complexes with DNA," Biochemistry, vol. 39, no. 18, pp. 5593-5599, 2000.

[26] R. J. Holmes, M. J. McKeage, V. Murray, W. A. Denny, and W. D. McFadyen, "cis-dichloroplatinum(II) complexes tethered to 9-aminoacridine-4-carboxamides: synthesis and action in resistant cell lines in vitro," Journal of Inorganic Biochemistry, vol. 85 , no. 2-3, pp. 209-217, 2001.

[27] M. D. Temple, P. Recabarren, W. D. McFadyen, R. Holmes, W. Denny, and V. Murray, "The interaction of DNA-targeted 9-aminoacridine-4-carboxamide platinum complexes with DNA in intact human cells," Biochimica et Biophysica Acta, vol. 1574, no. 3, pp. 223-230, 2002.

[28] E. T. Martins, H. Baruah, J. Kramarczyk, et al., "Design, synthesis, and biological activity of a novel non-cisplatintype platinum-acridine pharmacophore," Journal of Medicinal Chemistry, vol. 44, no. 25, pp. 4492-4496, 2001.

[29] J. M. Brow, C. R. Pleatman, and U. Bierbach, "Cytotoxic acridinylthiourea and its platinum conjugate produce enzyme-mediated DNA strand breaks," Bioorganic and Medicinal Chemistry Letters, vol. 12, no. 20, pp. 2953-2955, 2002.

[30] T. M. Augustus, J. Anderson, S. M. Hess, and U. Bierbach, "Bis(acridinylthiourea)platinum(II) complexes: synthesis, DNA affinity, and biological activity in glioblastoma cells," Bioorganic and Medicinal Chemistry Letters, vol. 13, no. 5, pp. 855-858, 2003.

[31] H. Baruah, C. S. Day, M. W. Wright, and U. Bierbach, "Metalintercalator-mediated self-association and one-dimensional aggregation in the structure of the excised major DNA adduct of a platinum-acridine agent," Journal of the American Chemical Society, vol. 126, no. 14, pp. 4492-4493, 2004.

[32] H. Baruah and U. Bierbach, "Biophysical characterization and molecular modeling of the coordinative-intercalative DNA monoadduct of a platinum-acridinylthiourea agent in a sitespecifically modified dodecamer," Journal of Biological Inorganic Chemistry, vol. 9, no. 3, pp. 335-344, 2004.

[33] M. C. Ackley, C. G. Barry, A. M. Mounce, et al., "Structureactivity relationships in platinum-acridinylthiourea conjugates: effect of the thiourea nonleaving group on drug stability, nucleobase affinity, and in vitro cytotoxicity," Journal of Biological Inorganic Chemistry, vol. 9, no. 4, pp. 453-461, 2004.
[34] J. R. Choudhury and U. Bierbach, "Characterization of the bisintercalative DNA binding mode of a bifunctional platinumacridine agent," Nucleic Acids Research, vol. 33, no. 17, pp. 5622-5632, 2005.

[35] C. G. Barry, C. S. Day, and U. Bierbach, "Duplex-promoted platination of adenine-N3 in the minor groove of DNA: challenging a longstanding bioinorganic paradigm," Journal of the American Chemical Society, vol. 127, no. 4, pp. 1160-1169, 2005.

[36] R. Guddneppanavar, G. Saluta, G. L. Kucera, and U. Bierbach, "Synthesis, biological activity, and DNA-damage profile of platinum-threading intercalator conjugates designed to target adenine," Journal of Medicinal Chemistry, vol. 49, no. 11, pp. 3204-3214, 2006.

[37] S. Ghirmai, E. Mume, H. Lundqvist, V. Tolmachev, and S. Sjöberg, "Synthesis and radioiodination of some 9aminoacridine derivatives for potential use in radionuclide therapy," Journal of Labelled Compounds and Radiopharmaceuticals, vol. 48, no. 12, pp. 855-871, 2005.

[38] J. Reedijk, "Improved understanding in platinum antitumour chemistry," Chemical Communications, no. 7, pp. 801-806, 1996.

[39] M. S. Khapasch, R. C. Seyler, and F. R. Mayo, "Coordination Compounds of Palladous Chloride," Journal of the American Chemical Society, vol. 60, pp. 882-884, 1938.

[40] G. M. Sheldrick, "Phase annealing in SHELX-90: direct methods for larger structures," Acta Crystallographica Section A, vol. 46, no. 6, pp. 467-473, 1990.

[41] G. M. Sheldrick, A Computer Program for Determination of Crystal Structure, University of Göttingen, Göttingen, Germany, 1994.

[42] J. A. Ibers and W. C. Hamilton, International Tables for X-ray Crystallography, vol. 4, The Kynoch Press, Birmingham, UK, 1974.

[43] J. Albert, J. Granell, J. Sales, M. Font-Bardía, and X. Solans, "Optically active exocyclic cyclopalladated derivatives of benzylidene- $(R)$-(1-phenylethyl)amines: syntheses and $\mathrm{X}$-ray molecular structures of $[\mathrm{Pd}(2-\{(\mathrm{E})-(R)$ $\left.\left.\left.\mathrm{CHMeN}=\mathrm{CH}-2^{\prime}, 6^{\prime}-\mathrm{Cl}_{2} \mathrm{C}_{6} \mathrm{H}_{3}\right\} \mathrm{C}_{6} \mathrm{H}_{4}\right) \mathrm{Cl}\left(\mathrm{PPh}_{3}\right)\right]$ and $[\mathrm{Pd}(2-$ $\left.\left.\left\{(Z)-(R)-\mathrm{CHMeN}=\mathrm{CH}-2^{\prime}, 6^{\prime}-\mathrm{F}_{2} \mathrm{C}_{6} \mathrm{H}_{3}\right\} \mathrm{C}_{6} \mathrm{H}_{4}\right) \mathrm{I}\left(\mathrm{PPh}_{3}\right)\right]$," Organometallics, vol. 14, no. 3, pp. 1393-1404, 1995.

[44] G. B. Deacon and J. H. S. Green, "Vibrational spectra of ligands and complexes-II Infra-red spectra (3650-375 $\mathrm{cm}^{-1}$ of triphenyl-phosphine, triphenylphosphine oxide, and their complexes," Spectrochimica Acta Part A, vol. 24, no. 7, pp. 845852, 1968.

[45] E. Boschmann and G. Wollaston, "Spectroscopy illustrateda lecture experiment," Journal of Chemical Education, vol. 59, no. 1, pp. 57-58, 1982.

[46] P. S. Belton, I. P. Parkin, D. J. Williams, and J. D. Woollins, "The reactions of sulphur-nitrogen species in liquid ammonia," Journal of the Chemical Society, Chemical Communications, no. 22, pp. 1479-1480, 1988.

[47] Y. Fuchita, H. Tsuchiya, and A. Miyafuji, "Cyclopalladation of secondary and primary benzylamines," Inorganica Chimica Acta, vol. 233, no. 1-2, pp. 91-96, 1995.

[48] J. Albert, M. Gómez, J. Granell, J. Sales, and X. Solans, "Five- and six-membered exo-cyclopalladated compounds of $N$-benzylideneamines. Synthesis and X-ray crystal structure of [cyclic] [PdBr$\left\{p-\mathrm{MeOC}_{6} \mathrm{H}_{3}\left(\mathrm{CH}_{2}\right)_{2}\right.$ $\left.\left.\mathrm{N}: \mathrm{CH}\left(2,6-\mathrm{Cl}_{2} \mathrm{C}_{6} \mathrm{H}_{3}\right)\right\}\left(\mathrm{PPh}_{3}\right)\right]$ and $\quad\left[\mathrm{PdBr}\left\{\mathrm{C}_{6} \mathrm{H}_{4} \mathrm{CH}_{2}\right.\right.$ $\left.\left.\mathrm{N}: \mathrm{CH}\left(2,6-\mathrm{Cl}_{2} \mathrm{C}_{6} \mathrm{H}_{3}\right)\right\}\left(\mathrm{PEt}_{3}\right)_{2}\right]$," Organometallics, vol. 9, no. 5 , pp. $1405-1413,1990$. 
[49] R. Bosque, C. López, X. Solans, and M. Font-Bardia, "heterodi- and heterotrimetallic compounds containing five-membered rings and $\sigma\left(\mathrm{Pd}-\mathrm{C}_{\mathrm{sp}}^{2}\right.$, ferrocene $)$ bonds. X-ray crystal structure of the meso-form of $[\mathrm{Pd} 2$ $\left.\left\{\mathrm{Fe}\left[\left(\eta^{5}-\mathrm{C}_{5} \mathrm{H}_{3}\right)-\mathrm{C}\left(\mathrm{CH}_{3}\right)=\mathrm{N}-\mathrm{C}_{6} \mathrm{H}_{5}\right]\right\}_{2} \mathrm{Cl}_{2}\left(\mathrm{PPh}_{3}\right)_{2}\right]$," Organometallics, vol. 18, no. 7, pp. 1267-1274, 1999.

[50] P. Ramani, R. Ranatunge-Bandarage, B. H. Robinson, and J. Simpson, "Ferrocenylamine complexes of platinum(II) including cycloplatinated derivatives," Organometallics, vol. 13, no. 2, pp. 500-510, 1994.

[51] J. Albert, R. M. Ceder, M. Gómez, J. Granell, and J. Sales, “Cyclopalladation of $\mathrm{N}$-mesitylbenzylideneamines. Aromatic versus aliphatic C-H activation," Organometallics, vol. 11, no. 4, pp. 1536-1541, 1992.

[52] P. S. Pregosin, Transition Metal Nuclear Magnetic Resonance, Elsevier, Zürich, Switzerland, 1991.

[53] P. R. R. Ranatunge-Bandarage, N. W. Duffy, S. M. Johnston, B. H. Robinson, and J. Simpson, "Synthesis and stereochemistry of bis(platinum) complexes of ferrocenylamines," Organometallics, vol. 13, no. 2, pp. 511-521, 1994.

[54] C. Navarro-Ranninger, F. Zamora, I. López-Solera, A. Monge, and J. R. Masaguer, "Cyclometallated complexes of $\mathrm{Pd}(\mathrm{II})$ and $\mathrm{Pt}(\mathrm{II})$ with 2-phenylimidazoline," Journal of Organometallic Chemistry, vol. 506, no. 1-2, pp. 149-154, 1996.

[55] J. E. Baldwin, R. H. Jones, C. Najera, and M. Yus, "Functionalisation of unactivated methyl groups through cyclopalladation reactions," Tetrahedron, vol. 41, no. 4, pp. 699-711, 1985.

[56] C. A. O’Mahoney, I. P. Parkin, D. J. Williams, and J. D. Woollins, "New metal-sulphur-nitrogen compounds from reactions in liquid ammonia. The X-ray structures of trans-bis(acetophenone dimethylhydrazone- $\left.N^{\alpha}\right)$ dichloropalladium(II) and [di(azathien)-1-yl- $\left.S^{1} N^{4}\right][2$-(hydrazonoethyl)phenyl]palladium(II)," Journal of the Chemical Society, Dalton Transactions, no. 6, pp. 1179-1185, 1989.

[57] C. Navarro-Ranninger, I. López-Solera, A. Alvarez-Valdés, et al., "Cyclometalated complexes of palladium(II) and platinum(II) with $N$-benzyl- and $N$-(phenylethyl)- $\alpha$ benzoylbenzylideneamine. Delocalization in the cyclometalated ring as a driving force for the orthometalation," Organometallics, vol. 12, no. 10, pp. 4104-4111, 1993.

[58] D. G. Allen, G. M. Mclaughlin, G. B. Robertson, W. L. Steffen, G. Salem, and S. B. Wild, "Resolutions involving metal complexation. Preparation and resolution of $(R, S)$ methylphenyl(8-quinolyl)phosphine and its arsenic analogue. Crystal and molecular structure of $(+)_{589}-[(R)$-dimethyl $(1-$ ethyl- $\alpha$-naphthyl)aminato- $\left.C^{2}, N\right]$ - $[(S)$-methylphenyl(8-quinolyl)phosphine]palladium(II) hexafluorophosphate," Inorganic Chemistry, vol. 21, no. 3, pp. 1007-1014, 1982.

[59] H. Jendralla, C. H. Li, and E. Paulus, "Efficient synthesis of $(R)$ - and $(S)-\left(6,6^{\prime}\right.$-difluorobiphenyl-2,2' -diyl $)$ bis(diphenylphosphine); electron-poor biphenyl-type ligands for transition metal catalysts," Tetrahedron Asymmetry, vol. 5, no. 7, pp. 1297-1320, 1994.

[60] J. W. L. Martin, F. S. Stephens, K. D. V. Weerasuria, and S. B. Wild, "Optically active arsenic macrocycles. Highly stereoselective syntheses of diastereomers and enantiomers of 14-membered macrocyclic dimers of $( \pm)$-2,3-dihydro- and ( \pm )-2,3,4,5-tetrahydro-1-methyl-1,4-benzazarsepine," Journal of the Chemical Society, vol. 110, no. 13, pp. 4346-4356, 1988.

[61] H. Adams, N. A. Bailey, T. N. Briggs, J. A. McCleverty, and H. M. Colquhoun, "Reactions of arylpalladium complexes with ammonia and chelating amines. Crystal and molecular structure of $\left[\mathrm{Pd}\left(o-\mathrm{C}_{6} \mathrm{H}_{4} \mathrm{CH}=\mathrm{NCH}_{2} \mathrm{CH}_{2} \mathrm{NH}_{2}\right)\right.$ $\left.\left(\mathrm{NH}_{2} \mathrm{CH}_{2} \mathrm{CH}_{2} \mathrm{NH}_{2}\right)\right]\left[\mathrm{PF}_{6}\right]$, a product of transamination and ligand substitution," Journal of the Chemical Society, Dalton Transactions, no. 8, pp. 1521-1526, 1982.

[62] M. V. Keck and S. J. Lippard, "Unwinding of supercoiled DNA by platinum-ethidium and related complexes," Journal of the American Chemical Society, vol. 114, no. 9, pp. 3386-3390, 1992.

[63] J. Ruiz, J. Lorenzo, L. Sanglas, et al., "Palladium(II) and platinum(II) organometallic complexes with the model nucleobase anions of thymine, uracil, and cytosine: antitumor activity and interactions with DNA of the platinum compounds," Inorganic Chemistry, vol. 45, no. 16, pp. 6347-6360, 2006.

[64] L. H. Pope, M. C. Davies, C. A. Laughton, C. J. Roberts, S. J. B. Tendler, and P. M. Williams, "Atomic force microscopy studies of intercalation-induced changes in plasmid DNA tertiary structure," Journal of Microscopy, vol. 199, no. 1, pp. 68-78, 2000.

[65] X. Qu, C. Wan, H.-C. Becker, D. Zhong, and A. H. Zewail, "The anticancer drug-DNA complex: femtosecond primary dynamics for anthracycline antibiotics function," Proceedings of the National Academy of Sciences of the United States of America, vol. 98, no. 25, pp. 14212-14217, 2001. 


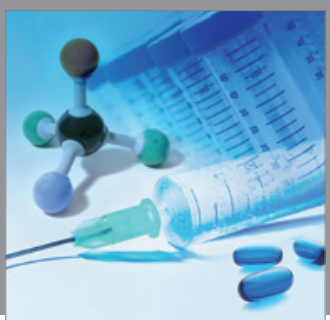

International Journal of

Medicinal Chemistry

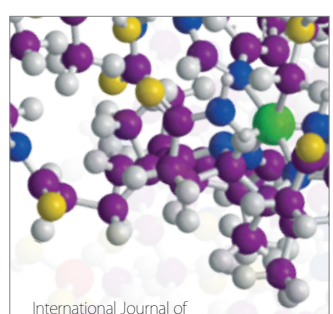

Carbohydrate Chemistry

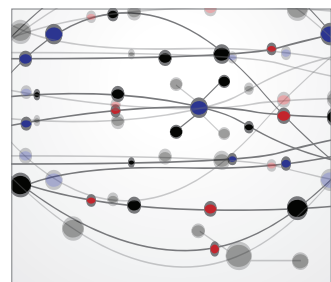

The Scientific World Journal
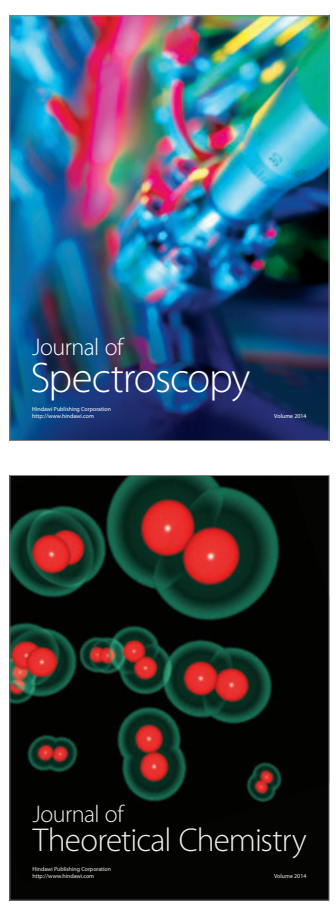
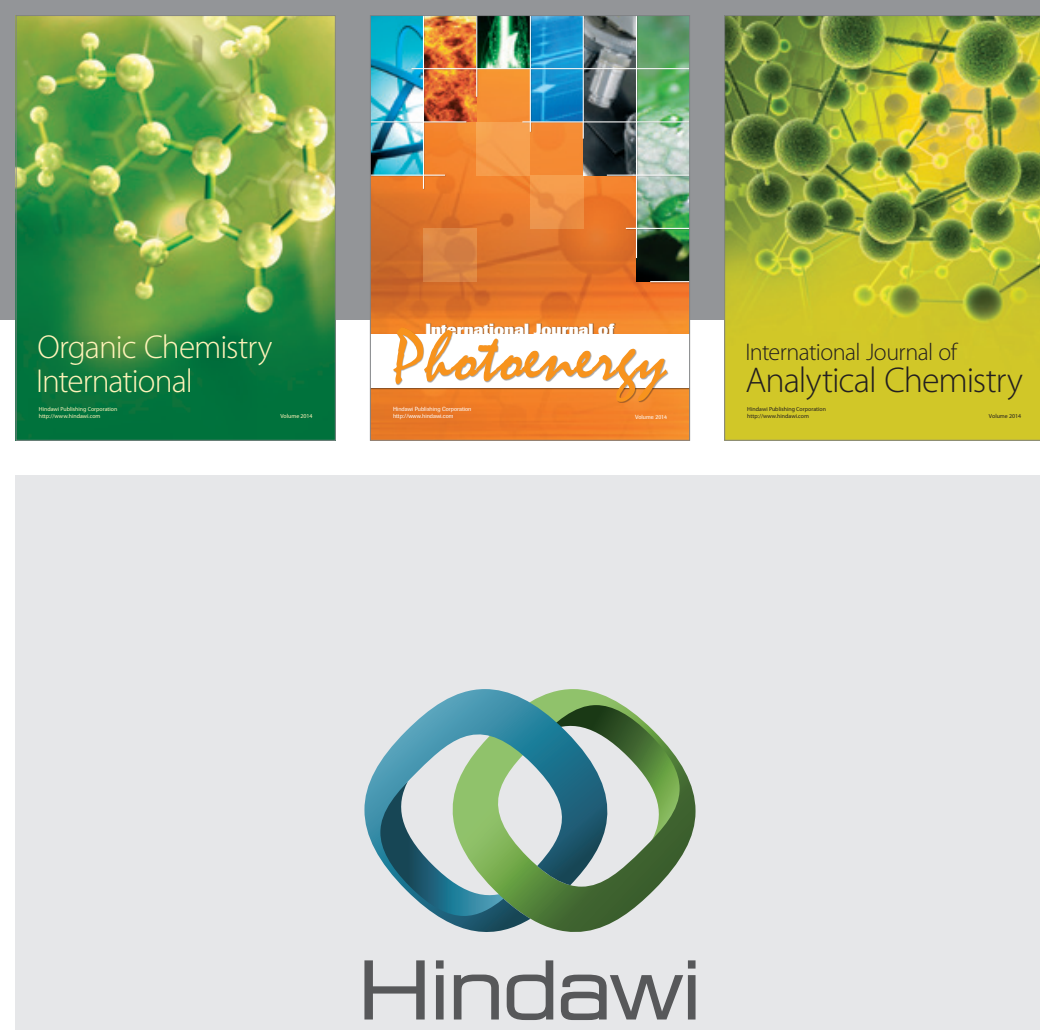

Submit your manuscripts at

http://www.hindawi.com
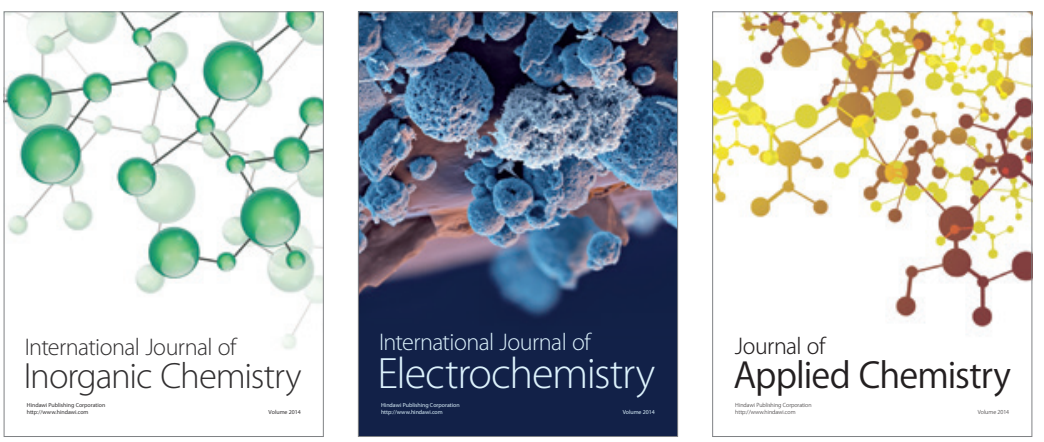

Journal of

Applied Chemistry
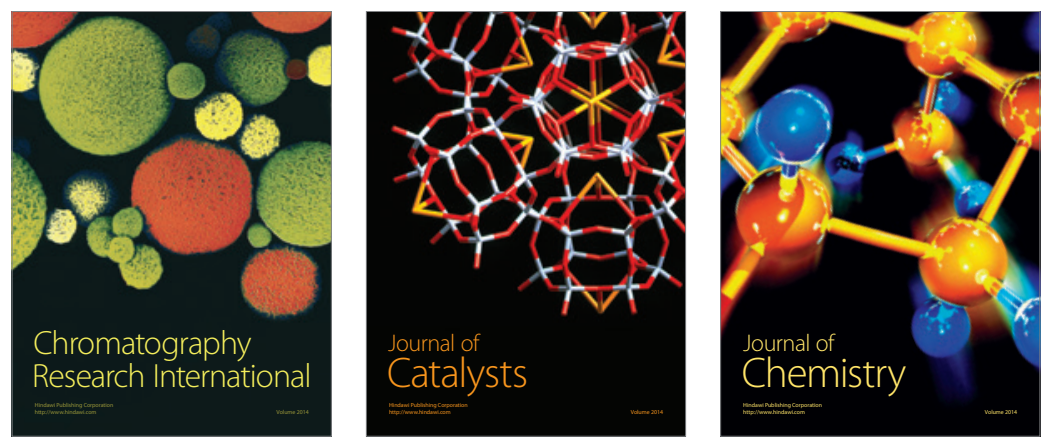
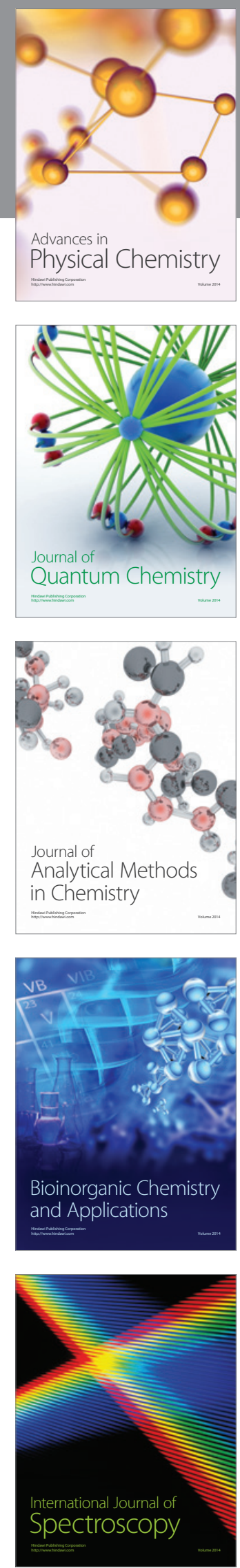